\title{
云南常绿阔叶林的植被地理研究
}

\author{
朱 华* \\ 中国科学院西双版纳热带植物园, 云南预腊 666303
}

\begin{abstract}
摘 要 云南具有极其丰富的生物多样性和以常绿阔叶林为优势的植被类型。该研究利用 6 个基于样方层面的 $1 \mathrm{hm}^{2}$ 样地资 料, 以及通过对整个植被类型的植物区系的调查, 对云南常绿阔叶林植被型的 3 个植被亚型(季风常绿阔叶林、半湿润常绿阔 叶林和中山湿性常绿榈叶林)的生态外貌特征、植物区系组成及其生物地理演化进行了研究。在样方层面, 尽管这 3 个常绿阔 叶林在树种组成上优势种均为壳斗科、樟科和山茶科植物, 但它们在种类组成、多样性、生态外貌和生物地理特征上呈现多 样化。分布在南部及西南部的季风常绿阔叶林物种组成极其丰富, 具有热带森林的生态外貌, 并以热带亚洲分布种为优势种。 主要分布在云南高原的半湿润常绿阔叶林和云南中部和北部山地的中山湿性常绿阔叶林具有亚热带常绿阔叶林的生态外貌 特征和以中国-喜马拉雅及中国特有种占优势, 是中国西南独特的植被类型。在植被亚型层面, 这3个常绿阔叶林的植物区系 (包括所有生活型的种子植物)中种数最多的科, 按地理成分均为世界分布型的科, 含种数较少的科则为其他各种分布型的 科。半湿润常绿阔叶林和中山湿性常绿阔叶林的植物区系, 热带分布属分别占总属数的 $44.91 \%$ 和 $44.04 \%$, 温带分布属占 46.29\%和 $48.19 \%$, 其中北温带分布属比例最高, 分别为 $18.36 \%$ 和 $19.95 \%$ 。季风常绿阔叶林植物区系则显示了不同的地理成分 格局: 热带分布属占总属数的 $78.05 \%$, 并以热带亚洲分布属占最高比例。通过对这3个常绿阔叶林的比较发现, 半湿润常绿阔 叶林和中山湿性常绿阔叶林除生态外貌特征有一定区别外, 在植物区系组成和地理成分上很接近, 它们在种的组成上, 与季 风常绿阔叶林的类似性仅为 $17.1 \%$ 和 $15.4 \%$ 。季风常绿阔叶林因其在植物区系和生态外貌上与后二者区别明显, 建议在云南植 被分类上划分一个独立的植被型, 它是东南亚低山常绿阔叶林分布在中国西南部热带北缘山地的一个植被类型。结合云南的 地质历史和古植物学资料, 认为云南的常绿阔叶林及其植物区系受晚中新世以来的地质历史事件深刻影响。半湿润常绿阔叶 林是中国西南独特而特有种丰富的植被类型, 由于严重的人为干扰破坏, 现已片断化或成为萌生灌从状, 应给予优先保护。 关键词 常绿阔叶林; 物种组成; 生态外貌; 生物地理; 云南
\end{abstract}

朱华 (2021). 云南常绿阔叶林的植被地理研究. 植物生态学报, 45, 00-00. DOI: 10.17521/cjpe.2020.0302

\section{Vegetation geography of evergreen broad-leaved forests in Yunnan, southwestern China}

\section{ZHU Hua*}

Xishuangbanna Tropical Botanical Garden, Chinese Academy of Sciences, Mengla, Yunnan 666303, China

\begin{abstract}
Aims Yunnan in southwestern China supports an extremely rich biodiversity and various vegetation types dominated by evergreen broad-leaved forest. Of these, three major types-monsoon evergreen broad-leaved forest (MEB), semi-wet evergreen broad-leaved forest (SWEB) and middle-montane wet evergreen broad-leaved forest (MMEB) - have not had a detailed scientific comparison. This article compares their floristic composition, species diversity, physiognomy, biogeography, and possible historical evolution, and gives suggestions for their conservation priorities.

Methods Six $1 \mathrm{hm}^{2}$ sampling plots, representing the three evergreen broad-leaved forests in Yunnan, were set up based on the present distribution of primary forest. All trees in each plot were identified and their diameter at breast height $(D B H)$ (minimum $5 \mathrm{~cm}$ ) and height measured. In four plots, all plants, including understory shrubs, herbs, lianas, and epiphytes, were surveyed for life forms and biogeographical element analyses at plot level. Importance value indices $(I V I)$ of tree species were calculated for each plot. At the vegetation level, all seed plants for the three major vegetation types were inventoried to compare their floristic composition and biogeography.

Important findings At plot level, the three forest types differ considerably in species composition, diversity,

收稿日期Received: 2020-09-04 接受日期Accepted: 2020-12-29

基金项目: 国家自然科学基金(41071040和31970223)和云南省科技厅-云南大学联合基金重大项目(2018FY001(-002))。Supported by the National Natural Science Foundation of China (41071040 and 31970223), and the major project of Yunnan Science and Technology Department-Yunnan University joint fund (2018FY001(-002)).

* 通信作者Corresponding author (zhuh@xtbg.ac.cn)
\end{abstract}


physiognomy, and biogeography, although they are commonly dominated by species of the families Fagaceae, Lauraceae and Theaceae. The MEB in southern Yunnan is extremely rich in species and is characterized by a tropical physiognomy. It is dominated by tropical Asian species, which is similar to the tropical lower montane evergreen forest in southeast Asia. The SWEB on plateaus and the MMEB in central and northern Yunnan are characterized by a subtropical physiognomy and are dominated by Sino-Himalayan and Chinese endemic species, which are unique in southwestern China. At the vegetation sub-type level, the three forest types commonly have species-rich families, which tend to have cosmopolitan distributions, but the families with fewer species exhibit other distribution types. The SWEB and the MMEB showed similar biogeographical patterns in the proportions of tropical (44.91\% and $44.04 \%$, respectively) and temperate (46.29\% and $48.19 \%)$ elements, with northern temperate distributions comprising the highest percentage (18.36\% in the SWEB and $19.95 \%$ in the MMEB) of total genera. In MEB, tropical elements comprised $78.05 \%$ of the total genera, with elements with tropical Asian distributions contributing the highest percentage (29.02\%). Similarity between SWEB and MMEB was high at species level, but lower similarities were shown between MEB and both of the SWEB and MMEB with 17.1\% and 15.4\% respectively at species levels. These results indicate divergence of the three forest floras, possibly from events in the geological history of Yunnan. The SWEB and the MMEB should be given high conservation values due to their uniqueness and abundant Chinese endemic species. Especially, the SWEB should be given the highest protection. Key words evergreen broad-leaved forest; species composition; physiognomy; biogeography; Yunnan

Zhu H (2021). Vegetation geography of evergreen broad-leaved forests in Yunnan, southwestern China. Chinese Journal of Plant Ecology, 45, 00-00. DOI: 10.17521/cjpe.2020.0302

云南地形和地貌复杂多样, 既有深切的高山峡 谷, 又有相对平坦的高原, 其西北部梅里雪山卡瓦 格博峰最高点海拔为 $6740 \mathrm{~m}$, 东南部的河口海拔 是76.4 m, 两地高差达6 $664 \mathrm{~m}$ 。云南地势总体上为 一个向南倾斜的大斜坡。在自然地理和生物地理上, 云南是热带亚洲生物区系向东亚和喜马拉雅亚热带 -温带生物区系的一个过渡地带和热带-亚热带常绿 森林的过渡地带(Ashton \& Zhu, 2020), 也是在植 物区系区划上的中国-日本植物区系与中国-喜马拉 雅植物区系的交汇过渡地带(Zhu, 2016)。

云南总体的气候格局是: 热带湿润气候主要在 南部低地; 热带干旱气候在海拔 $1000 \mathrm{~m}$ 以下的深 切河谷, 特别是北部的金沙江河谷, 热带干旱气候 上限可达海拔 $1300 \mathrm{~m}$; 亚热带气候主要在滇中高 原; 温带至寒温带气候在北部高山地区。由于云南 在南、北(金沙江河谷)低海拔区域均为热带气候, 可 以认为云南基本上是一个基带为热带的山体(朱华, 2008)。

云南具有极其丰富的生物多样性和以常绿阔叶 林为优势的多种植被类型。常绿阔叶林在云南植被 分类上被作为亚热带性质的一个植被型, 除局部的 山地苔藓常绿阔叶林和山顶(苔藓)矮林外, 它主要 包括3个植被亚型: 季风常绿阔叶林, 半湿润常绿 阔叶林和中山湿性常绿阔叶林(金振洲, 1979; 吴征 镒, 1987)。也有研究人员对中山湿性常绿阔叶林的 范畴作了扩展, 例如, Tang (2015) 把通常分布在中
山湿性常绿阔叶林带之上的所谓苔藓常绿阔叶林归 并到中山湿性常绿阔叶林植被亚型里。

本研究中的季风常绿阔叶林植被亚型(金振洲, 1979; 吴征镒, 1987), 经我们的研究, 是一种介于 热带季节雨林与亚热带常绿阔叶林之间的热带山地 常绿阔叶林, 它主要分布在云南西南、南部地区海 拔900-2000 m的山地(表1)。它的乔木层通常为2层, 群落高25-35 m, 主要由壳斗科的栲属(Castanopsis) 和石栎属(Lithocarpus)植物、大戟科、樟科、山茶科 (主要是西南木荷(Schima wallichii)和茶梨(Anneslea fragrans))等树种组成, 林冠趋于整齐而彼此相连; 灌木、草本层植物种类较少, 主要是上层乔木的幼 苗, 层间木质藤本较丰富, 但附生植物少见。这类热 带山地上的常绿阔叶林无论在种数和个体数上, 常 绿的乔木均占乔木总数的 $90 \%$ 以上, 整个森林呈常 绿季相。由于季风常绿阔叶林具有较多热带森林生 态外貌和显著的热带亚洲植物区系组成, 与东南亚 的低山常绿阔叶林是同一类型的植被(Zhu et al., 2005, 2006, 2015, 2019; Zhu, 2006, 2019; 朱华等, 2015)。

半湿润常绿阔叶林植被亚型主要分布在滇中高 原海拔1 500-2 600 m的山地, 是滇中高原的地带性 代表植被(特有植被), 除在一些保护区外，大部分 已被破坏, 形成萌生灌从状次生植被和次生林。半 湿润常绿阔叶林在石灰岩山地和非石灰岩山地均有 分布。该类森林具有 2 个乔木层, 高20-25 m, 主要

www.plant-ecology.com 
表1 云南常绿阔叶林的3个植被亚型的分布及生境

Table 1 Distribution and habitats of the three evergreen broad-leaved forest sub-type in Yunnan

\begin{tabular}{|c|c|c|c|c|}
\hline $\begin{array}{l}\text { 森林类型 } \\
\text { Forest type }\end{array}$ & $\begin{array}{l}\text { 主要分布区域 } \\
\text { Main distribution area }\end{array}$ & $\begin{array}{c}\text { 分布海拔 } \\
\text { General altitude } \\
\text { distribution (m) }\end{array}$ & $\begin{array}{c}\text { 年平均气温 } \\
\text { Mean annual air } \\
\text { temperature }\left({ }^{\circ} \mathrm{C}\right)\end{array}$ & $\begin{array}{c}\text { 年降水量 } \\
\text { Mean annual } \\
\text { precipitation (mm) }\end{array}$ \\
\hline $\begin{array}{l}\text { 季风常绿阔叶林 } \\
\text { Monsoon evergreen broad-leaved forest }\end{array}$ & $\begin{array}{l}\text { 云南南部及西南部低山 } \\
\text { Lower montane in southern and } \\
\text { southwestern Yunnan }\end{array}$ & $900-2000$ & $18-20$ & $1350-1600$ \\
\hline $\begin{array}{l}\text { 半湿润常绿阔叶林 } \\
\text { Semi-wet evergreen broad-leaved forest }\end{array}$ & $\begin{array}{l}\text { 云南中部高原 } \\
\text { Plateau in central Yunnan }\end{array}$ & $1500-2600$ & $14-17$ & $900-1200$ \\
\hline $\begin{array}{l}\text { 中山湿性常绿阔叶林 } \\
\text { Middle montane wet evergreen broad-leaved } \\
\text { forest }\end{array}$ & $\begin{array}{l}\text { 云南中部和北部山地 } \\
\text { Montanes in central and northern Yunnan }\end{array}$ & $2000-2900$ & $10-12$ & $1800-2000$ \\
\hline
\end{tabular}

由壳斗科的高山栲(Castanopsis delavayi)、元江栲 (Castanopsis orthacantha)、滇青冈(Cyclobalanopsis glaucoides)、黄毛青冈(Cyclobalanopsis delavayi)、 光叶石栎(Lithocarpus kontumensis)及山茶科、冬青 科和木兰科植物组成, 但在灰岩山地, 还常见漆树 科植物黄连木(Pistacia chinensis)、清香木(Pistacia weinmannifolia)、木兰科的山玉兰(Magnolia delavayi) 等。灌木层最常见的是马桑(Coriaria nepalensis)、 铁仔(Myrsine africana)、皮袋香(Michelia yunnane$n s i s) 、$ 碎米杜鹃(Rhododendron spiciferum)、大白杜 鹃(Rhododendron decorum)等。半湿润常绿榈叶林具 有亚热带生态外貌特征, 中国特有种占优势, 其优 势物种组成在该植被类型中变化不大, 它是中国西 部亚热带地区的水平地带性植被(Zhu et al., 2019)。

中山湿性常绿阔叶林植被亚型主要分布在海拔 $2000 \mathrm{~m}$ 以上的山地云雾带, 通常具有 2 个乔木层, 群落高20-25 m, 上层乔木构成相对平整的林冠, 林中附生植物非常丰富。中山湿性常绿润叶林乔木 层以壳斗科、杜鹃花科植物如大树杜鹃(Rhododendron protistum var. gigantum)、马樱花(Rhododendron delavayi)、樟科、木兰科、山茶科、山矾科、冬青 科等植物占优势。尽管在不同地区的分布海拔各有 不同, 如哀牢山(2 300-2 $600 \mathrm{~m})$ (朱华和阇丽春, 2009)、无量山(2 200-2 900 m)(彭华和吴征镒, 1998)、永德大雪山(2 000-2 $800 \mathrm{~m})($ 刘恩德和彭华, 2007)、高黎贡山(2 000-2 600 m)(孟广涛等, 2013)、 小百草岭(2 500-3 $400 \mathrm{~m}$ )(王利松和彭华, 2004)等, 在植物区系组成和生态外貌上具有亚热带常绿阔叶 林特征, 但其分布生境却是暖温带-温带气候。它的 植物区系成分显示了具有热带起源背景, 并以中国 -喜马拉雅及中国特有种占优势。现今分布在温带气 候条件下, 这种分布格局暗示了横断山区近代的迅 速抬升与它的演化密切相关(Zhu et al., 2016; 朱华,
2016)。

古植物学研究揭示, 云南的常绿阔叶林在晚中 新世时就已开始分异(Jacques et al., 2014, 2015), 在 中新世时, 云南西南部为热带性质的植被, 在东部 和东北部为亚热带性质的植被(Huang et al., 2016)。 云南的植物区系和植被的组成与分布格局可能在 2300 万年前的中新世就基本形成了(朱华, 2018; Zhu, 2019)。最近的古植物学和古植被的研究揭示, 横断山高寒植物多样性的积累始于早渐新世(Ding et al., 2020); 云南吕合盆地早渐新世(大约3 300至 3200 万年前)就已有了与现代该地区几乎无形态学 区别的栎属(Quercus)、桤木属(Alnus)、桦木属 (Betula)、我耳枥属(Carpinus)、榛属(Corylus/Ostrya) 等植物(Tang et al., 2020); 植物化石研究也揭示了 青藏高原中部在4 700万年前就已有了亚热带森林 植被(Su et al., 2020)。这些古植物学的发现可以说颠 覆了我们对云南植被演化历史的常规认识。通过古 植物学研究与现代云南常绿阔叶林的比较能为揭示 云南常绿阔叶林的演化历史提供依据。

本研究在样方层面对云南的常绿阔叶林进行了 传统的群落生态学研究, 同时在植被亚型层面, 对 植物区系组成、特征及生物地理进行了研究。根据 我多年对云南植被的调查, 在样方层面, 一个样方 仅能反映植被的局部地段的物种组成, 并不能代表 整个植被类型的植物区系。云南复杂的地形地貌和 多样的局部微环境造就了非常丰富的物种多样性。 同一个植被类型, 在不同的地方, 同样的取样面积 的物种比较显示, 除极少数共同优势乔木树种外, 物种的总体差异很大(Zhu et al., 2016)。为了弥补对 整个植被类型的植物区系组成的认识, 我对本文所 研究的 3 个植被类型的植物区系进行了全面的调查 统计, 并与样方层面的资料进行比较, 通过样方层 面的资料来反映植被类型的生态外貌特征和物种丰 
富度情况, 如生活型谱、叶级谱等, 而利用植被型层 面的物种调查资料来体现植被类型的植物区系组成 及演化历史。通过对植被的植物区系研究, 能为探 索植被的来龙去脉提供线索(Zhu et al., 2020)。期望 通过群落生态学与区系地理学及古植物学研究的结 合, 对具体植被进行综合研究, 更深入地探讨植被 的物种组成、群落结构特征以及形成与演化历史。 结合群落生态学和区系地理学, 对具体植被进行综 合研究, 在对云南热带森林的研究上取得了较好的 结果(Zhu, 1997; Zhu et al., 2015, 2016), 这样的方法 是值得推广的。Spicer等(2020)比较了热带与温带森 林的植物生长型, 发现温带森林中树种的种数仅占 所有植物生长型种数的 $7 \%$, 热带森林中树种的种 数也仅占所有植物生长型种数的 $30 \%$, 只关注树种 的调查会低估了森林群落的物种多样性。本文比较 了云南常绿阔叶林植被型的 3 个植被亚型的生活型 谱和所占种数比例, 期望研究人员能关注森林群落 除树种之外的其他生活型的植物调查, 提升群落生 物多样性的完整性。

\section{1 材料和方法}

分别在样方和植被亚型层面上对云南的常绿阔 叶林进行研究。在样方层面, 设置代表云南常绿阔 叶林植被型的 3 个亚型的 6 个 $1 \mathrm{hm}^{2}$ 样地。目前云南的 半湿润常绿阔叶林植被亚型只呈斑块状分散保存在 一些保护区及其他保护地中, 本研究的样地分别设 立在云南石林(石灰岩地区)和云南宾川鸡足山。中 山湿性常绿阔叶林植被亚型仍有大面积且连续的原 始森林存在于云南中部的哀牢山国家级自然保护区, 在该保护区设立了 2 个样地。季风常绿润叶林植被 亚型的样地选择在云南南部, 那里是该类常绿阔叶 林的主要分布区域。样地设置的具体地点是: 季风 常绿阔叶林样地 1 , 预腊县预仑, $21.57^{\circ} \mathrm{N}, 101.16^{\circ} \mathrm{E}$, 海拔 $1170 \mathrm{~m}$; 样地2, 思茅菜阳河, $22.57^{\circ} \mathrm{N}, 101.2^{\circ}$ $\mathrm{E}$, 海拔 $1380 \mathrm{~m}$ 。半湿润常绿阔叶林样地 1 , 宾川县 鸡足山, $25.96^{\circ} \mathrm{N}, 100.38^{\circ} \mathrm{E}$, 海拔2 $450 \mathrm{~m}$; 样地2, 昆明石林(石灰岩生境), $24.64^{\circ} \mathrm{N}, 103.35^{\circ} \mathrm{E}$, 海拔 $1950 \mathrm{~m}$ 。中山湿性常绿阔叶林样地1, 景东徐家坝, $24.54^{\circ} \mathrm{N}, 101.03^{\circ} \mathrm{E}$, 海拔2 $450 \mathrm{~m}$; 样地2, 镇元千 家寨, $24.28^{\circ} \mathrm{N}, 101.26^{\circ} \mathrm{E}$, 海拔2 $320 \mathrm{~m}$ 。鉴定每个 样地中的所有乔木树种, 测量了胸径 $(D B H) \geqslant 5 \mathrm{~cm}$ 和高度。为统计样地内植物的生活型谱及在样方层
面分析其植物区系物种的分布区类型，对其中 4 个 样地的所有植物, 包括林下灌木、草本植物、藤本 植物和附生植物进行调查。基于样地资料, 分析每 个样地树木的重要值指数(IVI)(Curtis \& McIntosh, 1951)和物种多样性。样方所在群落斑块的生态外貌 特征(生活型谱和叶级谱)使用Raunkiaer (1934)提出, Mueller-Dombois和Ellenberg (1974)修订的标准进行 分析。根据 4 个样方记录到的物种, 查阅每个种的世 界分布情况, 参考吴征镒(1991)及吴征镒等(2006) 对分布区类型的划分依据, 确定各物种的分布区类 型。在样地层面, 对这 3 个常绿阔叶林的物种组成、 多样性、生态外貌特征和生物地理进行比较研究, 以评价其相似性和变异性。另一方面, 依据多年的 野外调查, 编制云南这 3 个主要常绿阔叶林的植物 区系名录。季风常绿阔叶林在其主要分布区内记录 野生种子植物164科834属1 924种; 半湿润常绿阔 叶林记录野生种子植物 147 科 795 属 2228 种; 中山 湿性常绿阔叶林主要依据对哀牢山的该类森林植物 区系的研究, 记录种子植物110科386属821种(朱华, 2016)。科的界定依据APG III (Chase \& Reveal 2009; The Angiosperm Phylogeny Group, 2009), 种名按 w3TROPICOS 数据库校对 (http://mobot.mobot.org/ $\mathrm{W} 3 \mathrm{~T} / \mathrm{Search} / \mathrm{vast} . \mathrm{html}$ )。基于野生种子植物名录, 我 们分析了这3个植被亚型的植物区系特征和科属的 地理属性。种子植物属的分布区类型根据吴征镒 (1991)及吴征镒等(2006)的分类，科的分布区类型 根据吴征镒等(2003)的划分。比较它们在植被亚型 层面的植物区系和地理成分, 分析这 3 个常绿阔叶 林之间的区系相似性、变异性和可能的生物地理亲 缘关系。最后, 将这 3 个常绿阔叶林的区系组成和地 理成分与Jacques等(2014)对云南古植被的研究进行 比较, 讨论它们可能的起源与演化。

\section{2 结果}

\section{1 树种组成}

三个常绿阔叶林植被亚型样地树种优势科组成 见表2, 优势种组成见表3。尽管这 3 个常绿阔叶林样 地的乔木树种都以壳斗科、山茶科和樟科植物占优 势, 但它们在具体的优势种组成上却呈现多样化。 在季风常绿阔叶林, 乔木树种以壳斗科的短刺栲 (Castanopsis echidnocarpa), 小果栲(C. fleuryi), 刺 栲(C. hystrix), 白穗石栎(Lithocarpus craibianus), 


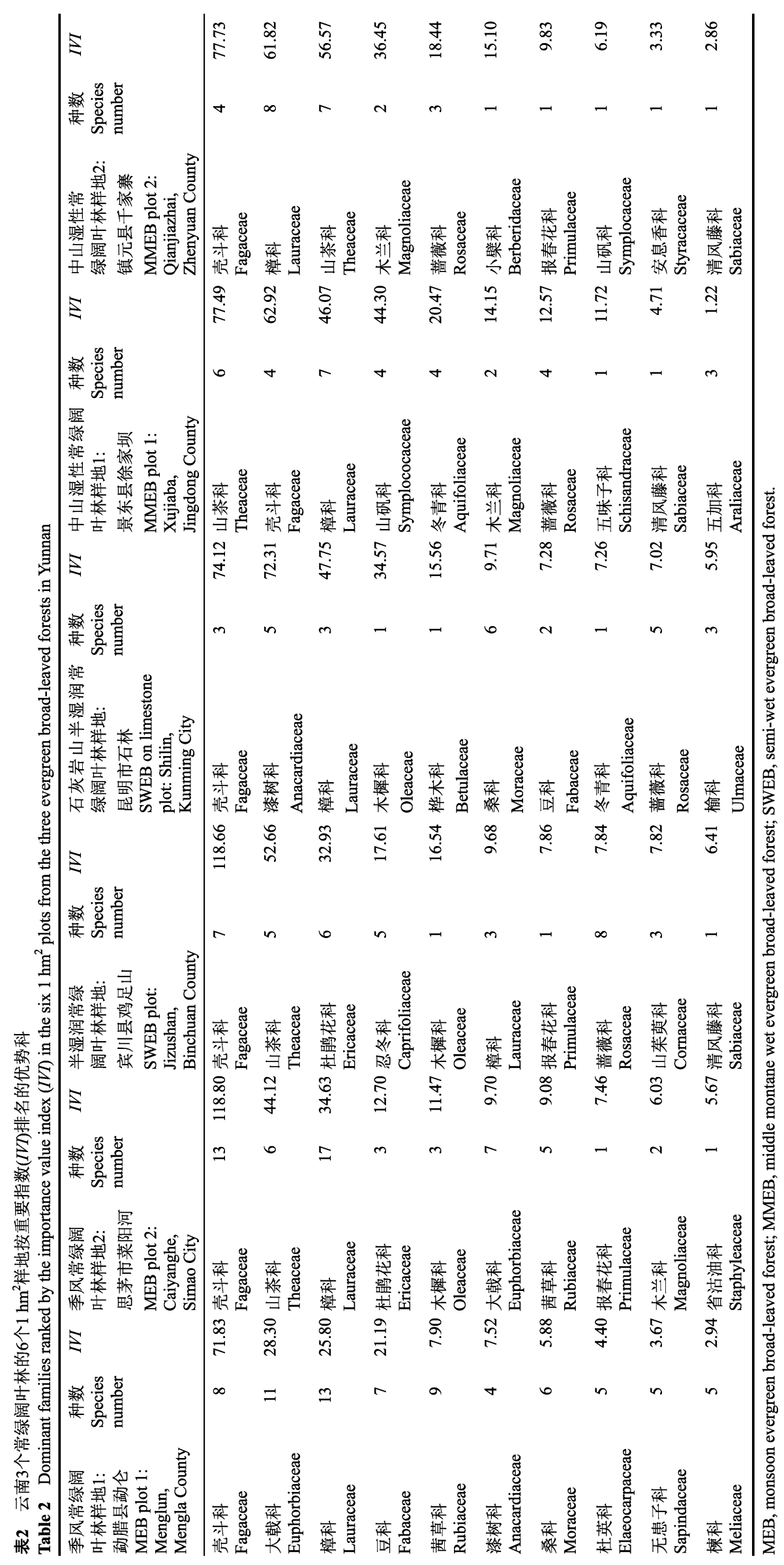


6 植物生态学报 Chinese Journal of Plant Ecology 2021, 45 (*): 00-00

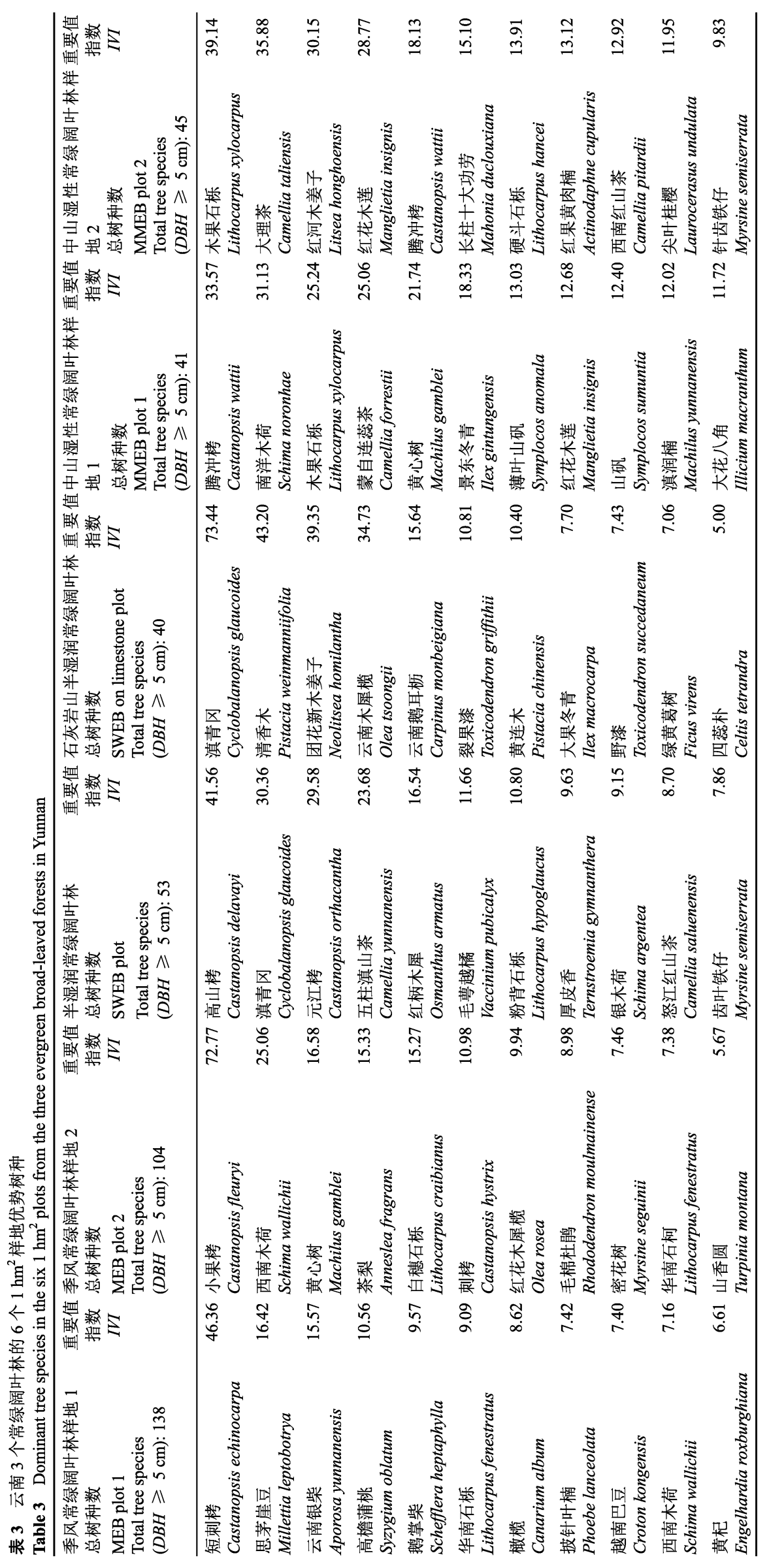




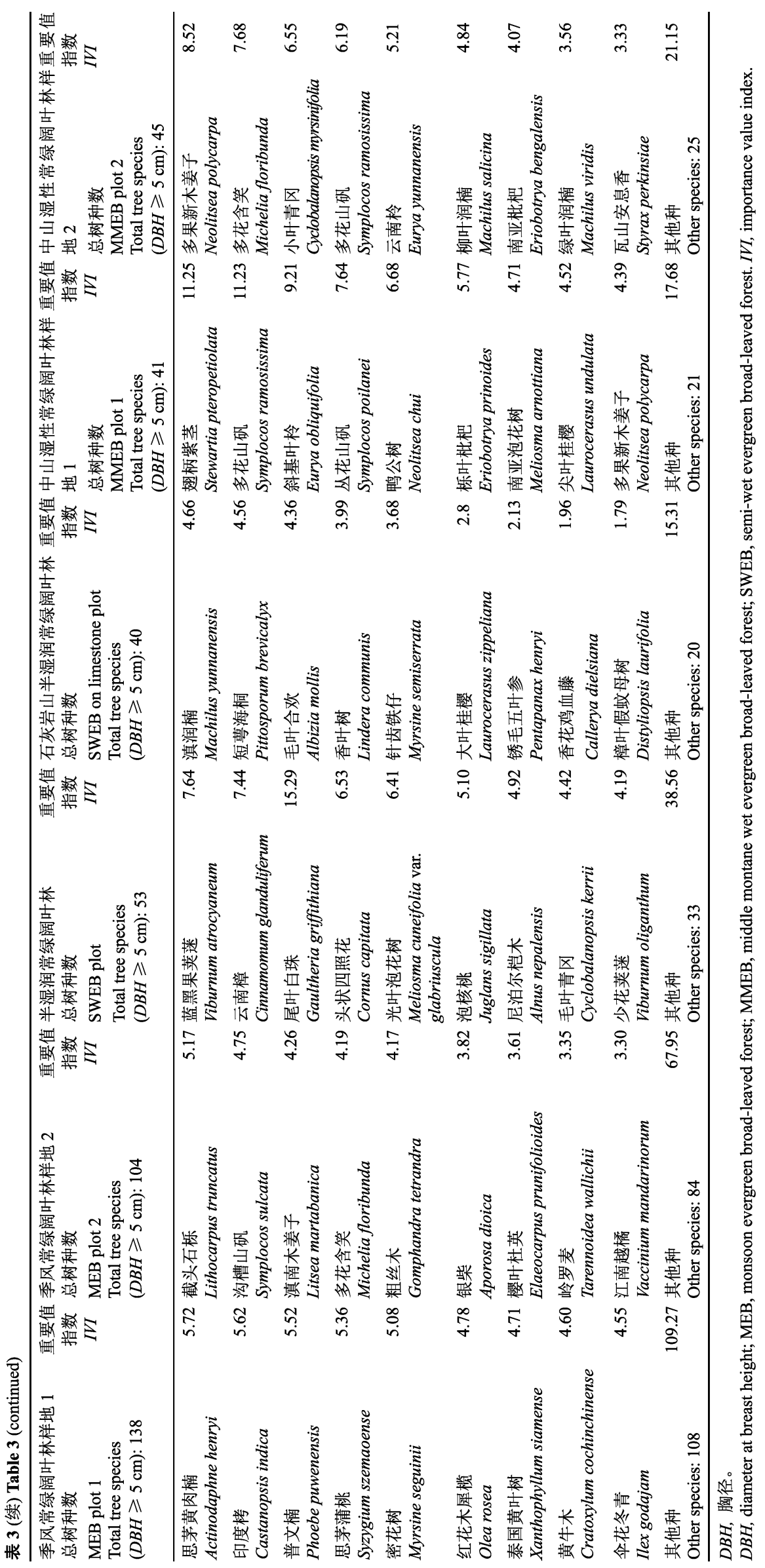


华南石柇(L. fenestratus), 以及山茶科的西南木荷占 优势, 大戟科和茜草科植物占亚优势。在半湿润常 绿阔叶林, 壳斗科的滇青冈在石灰岩山及非石灰岩 山生境均占优势, 而高山栲和元江栲在非石灰岩山 生境占优势, 但漆树科的清香木及黄连木, 樟科的 团花新木姜子(Neolitsea homilantha), 木樨科的云南 木犀榄(Olea tsoongii)则可在石灰岩山生境成为亚 优势种。在中山湿性常绿阔叶林, 虽以壳斗科和茶 科树种占优势, 如腾冲栲 (C. wattii), 木果石栋 ( $L$. xylocarpus), 南洋木荷 (Schima noronhae), 大理茶 (Camellia taliensis), 蒙自连芯茶(C. forrestii), 但樟 科、木兰科、冬青科、山矾科、小檗科等科的种类 仍较为丰富, 如红河木姜子(Litsea honghoensis)、 黄心树 (Machilus gamblei)、红花木莲 (Manglietia insignis)、景东冬青(Ilex gintungensis)、薄叶山矾 (Symplocos anomala)、长柱十大功劳(Mahonia duclouxiana)等(表3)。

\section{2 物种多样性}

三个常绿阔叶林的 4 个 $1 \mathrm{hm}^{2}$ 样地植物区系编目 调查(包括了样地中所有生活型的植物)显示, 季风 常绿润叶林在 $1 \mathrm{hm}^{2}$ 样地上记录有维管束植物 360 种; 半湿润常绿阔叶林在非石灰岩山生境记录有维管束 植物174种, 在石灰岩山生境记录有144种; 中山湿 性常绿阔叶林记录有维管束植物 166 种。在这 3 个常 绿阔叶林样地的乔木种数上, 季风常绿阔叶林最多,
2 个 $1 \mathrm{hm}^{2}$ 样地上有 $D B H \geqslant 5 \mathrm{~cm}$ 的树种 128 和 104 种; 半湿润常绿阔叶林在非石灰岩山样地有树种53种, 在石灰岩山样地有 40 种; 2 个中山常绿阔叶林样地 分别有树种 41 和 45 种。

\section{3 生态外貌特征}

表4列出了这 3 个常绿阔叶林植被亚型的植物生 活型谱。季风常绿阔叶林具有大高位芽植物和更多 的小高位芽植物, 更少的地面芽植物; 中山湿性常 绿阔叶林具有最高比例的中高位芽植物和附生植物; 半湿润常绿阔叶林在石灰岩生境的样地具有更多的 地面芽植物和藤本植物。3个常绿阔叶林树种的叶特 征列于表5。季风常绿阔叶林具有更多的大叶、复叶 以及全缘叶树种; 中山湿性常绿阔叶林具有更小比 例的全缘叶树种。

\section{4 种的地理成分}

三个常绿阔叶林样地物种的地理成分(莿类植 物除外)见表6。季风常绿阔叶林样地329个种子植物 中, 热带分布种合计占总种数的 $70.52 \%$, 其中热带 亚洲分布种占总种数的 $64.73 \%$; 半湿润常绿阔叶林 和中山湿性常绿阔叶林则是以温带分布种占优势, 分别占总种数的 $72.88 \%$ (石灰岩生境)、78.67\% (非 石灰岩生境)和 $80.27 \%$, 并以中国特有种、中国-喜马 拉雅分布种和东亚分布种为主。

\section{5 常绿阔叶林的植物区系和生物地理}

一个样地里的物种, 仅能反映同一植被类

表4 云南3个常绿阔叶林生活型谱比较( 4 个 $1 \mathrm{hm}^{2}$ 样方)

Table 4 Comparisons of plant life forms in the four $1 \mathrm{hm}^{2}$ plots from the three evergreen broad-leaved forests in Yunnan

\begin{tabular}{|c|c|c|c|c|c|c|c|c|}
\hline \multirow[t]{2}{*}{ 生活型 Life form } & \multicolumn{2}{|c|}{$\begin{array}{l}\text { 季风常绿阔叶林样地 } 1 \\
\text { MEB plot } 1\end{array}$} & \multicolumn{2}{|c|}{$\begin{array}{c}\text { 半湿润常绿阔叶林样地 } \\
\text { SWEB plot }\end{array}$} & \multicolumn{2}{|c|}{$\begin{array}{c}\text { 石灰岩山半湿润常绿阔叶林样地 } \\
\text { SWEB on limestone plot }\end{array}$} & \multicolumn{2}{|c|}{$\begin{array}{c}\text { 中山湿性常绿阔叶林样地1 } \\
\text { MMEB plot } 1\end{array}$} \\
\hline & $\begin{array}{l}\text { 种数 } \\
\text { Species } \\
\text { number }\end{array}$ & $\begin{array}{c}\text { 种数比例 } \\
\text { Percent of species } \\
\text { number (\%) }\end{array}$ & $\begin{array}{l}\text { 种数 } \\
\text { Species } \\
\text { number }\end{array}$ & $\begin{array}{c}\text { 种数比例 } \\
\text { Percent of species } \\
\text { number }(\%)\end{array}$ & $\begin{array}{l}\text { 种数 } \\
\text { Species } \\
\text { number }\end{array}$ & $\begin{array}{l}\text { 种数比例 } \\
\text { Percent of species } \\
\text { number }(\%)\end{array}$ & $\begin{array}{l}\text { 种数 } \\
\text { Species } \\
\text { number }\end{array}$ & $\begin{array}{l}\text { 种数比例 } \\
\text { Percent of species } \\
\text { number (\%) }\end{array}$ \\
\hline 大高位芽 Megaphanerophytes & 22 & 6.11 & 0 & 0.00 & 0 & 0.00 & 1 & 0.60 \\
\hline 中高位芽 Mesophanerophytes & 59 & 16.39 & 27 & 15.52 & 20 & 13.89 & 43 & 25.90 \\
\hline 小高位芽 Microphanerophytes & 108 & 30.00 & 35 & 20.11 & 20 & 13.89 & 13 & 7.83 \\
\hline 矮高位芽 Nanophanerophytes & 33 & 9.17 & 16 & 9.20 & 10 & 6.94 & 9 & 5.43 \\
\hline $\begin{array}{l}\text { 地上芽及草本高位芽 } \\
\text { Chamaephytes and Herbaceous } \\
\text { phanerophytes }\end{array}$ & 42 & 11.67 & 36 & 20.69 & 26 & 18.06 & 30 & 18.07 \\
\hline 地下芽 Geophytes & 19 & 5.28 & 4 & 2.30 & 5 & 3.47 & 7 & 4.22 \\
\hline 地面芽 Hemicryptophytes & 16 & 4.44 & 16 & 9.20 & 25 & 17.36 & 21 & 12.65 \\
\hline 藤本植物 Liana & 54 & 15.00 & 35 & 20.11 & 32 & 22.22 & 18 & 10.84 \\
\hline 附生植物 Epiphytes & 7 & 1.94 & 5 & 2.87 & 6 & 4.17 & 24 & 14.46 \\
\hline 总种数 Total species & 360 & 100.00 & 174 & 100.00 & 144 & 100.00 & 166 & 100.00 \\
\hline
\end{tabular}

MEB, monsoon evergreen broad-leaved forest; MMEB, middle montane wet evergreen broad-leaved forest; SWEB, semi-wet evergreen broad-leaved forest. 
表5＼cjkstart云南3个常绿榈叶林叶特征比较 $\left(4\right.$ 个 $1 \mathrm{hm}^{2}$ 样方资料)

Table 5 Comparisons of leaf features of tree species in the four $1 \mathrm{hm}^{2}$ plots from the three evergreen broad-leaved forests in Yunnan

\begin{tabular}{|c|c|c|c|c|c|c|c|c|c|}
\hline \multicolumn{2}{|l|}{$\begin{array}{l}\text { 叶特征 } \\
\text { Leaf feature }\end{array}$} & \multicolumn{2}{|c|}{$\begin{array}{c}\text { 季风常绿阔叶林样地1 } \\
\text { MEB plot } 1 \\
\end{array}$} & \multicolumn{2}{|c|}{$\begin{array}{c}\text { 半湿润常绿阔叶林样地 } \\
\text { SWEB plot }\end{array}$} & \multicolumn{2}{|c|}{$\begin{array}{c}\text { 石灰岩山半湿润常绿阔叶林样地 } \\
\text { SWEB on limestone plot } \\
\end{array}$} & \multicolumn{2}{|c|}{$\begin{array}{c}\text { 中山湿性常绿阔叶林样地 } 1 \\
\text { MMEB plot } 1\end{array}$} \\
\hline & & $\begin{array}{l}\text { 种数 } \\
\text { Species } \\
\text { number }\end{array}$ & $\begin{array}{c}\text { 种数比例 } \\
\text { Percent of species } \\
\text { number (\%) }\end{array}$ & $\begin{array}{l}\text { 种数 } \\
\text { Species } \\
\text { number }\end{array}$ & $\begin{array}{c}\text { 种数比例 } \\
\text { Percent of species } \\
\text { number (\%) }\end{array}$ & $\begin{array}{l}\text { 种数 } \\
\text { Species } \\
\text { number }\end{array}$ & $\begin{array}{c}\text { 种数比例 } \\
\text { Percent of species } \\
\text { number (\%) }\end{array}$ & $\begin{array}{l}\text { 种数 } \\
\text { Species } \\
\text { number }\end{array}$ & $\begin{array}{c}\text { 种数比例 } \\
\text { Percent of species } \\
\text { number (\%) }\end{array}$ \\
\hline \multirow{4}{*}{$\begin{array}{l}\text { 叶级 }^{1} \\
\text { Leaf size }^{1}\end{array}$} & 大叶 Macrophyll & 14 & 10.14 & 0 & 0.00 & 0 & 0.00 & 1 & 2.44 \\
\hline & 中叶 Mesophyll & 81 & 58.70 & 30 & 56.60 & 21 & 52.50 & 23 & 56.10 \\
\hline & 小叶 Microphyll & 41 & 29.71 & 23 & 43.40 & 17 & 42.50 & 17 & 41.46 \\
\hline & 微叶 Nanophyll & 2 & 1.45 & 0 & 0.00 & 2 & 5.00 & 0 & 0.00 \\
\hline \multirow{2}{*}{$\begin{array}{l}\text { 叶型 } \\
\text { Leaf type }\end{array}$} & 复叶 Compound leaf & 29 & 20.29 & 3 & 5.66 & 6 & 15.00 & 4 & 9.8 \\
\hline & 单叶 Single leaf & 109 & 78.99 & 50 & 94.34 & 34 & 85.00 & 37 & 90.2 \\
\hline \multirow{2}{*}{$\begin{array}{l}\text { 叶缘 } \\
\text { Leaf margin }\end{array}$} & 全缘 Entile & 122 & 88.41 & 36 & 67.92 & 23 & 57.50 & 20 & 48.78 \\
\hline & 非全缘 None entile & 16 & 11.59 & 17 & 36.08 & 17 & 42.50 & 21 & 51.22 \\
\hline \multicolumn{2}{|c|}{ 总种数 Total species } & 138 & 100.00 & 53 & 100.00 & 40 & 100.00 & 41 & 100.00 \\
\hline
\end{tabular}

${ }^{1}$ Webb (1959)从 Raunkiaer 在叶级尺寸上划分的中叶里把叶面积为 2 025-4 $500 \mathrm{~mm}^{2}$ 的叶子分出为中小叶型。中国植物学家习惯于用 Raunkiaer 的中叶 划分, 该表仍用 Raunkiaer 的中叶概念, 即叶面积 2 025-18 $225 \mathrm{~mm}^{2}$ 为中叶。

${ }^{1}$ Webb (1959) split off the lower end of Raunkiaer's big mesophyll class $\left(2025-18225 \mathrm{~mm}^{2}\right)$ as notophylls $\left(2025-4500 \mathrm{~mm}^{2}\right)$. Chinese botanists are more familiar with Raunkiaer's big mesophyll class, and here we use Raunkiaer' big mesophyll class, i.e., the leaf area $2025-18225 \mathrm{~mm}^{2}$ is for mesophyll. MEB, monsoon evergreen broad-leaved forest; MMEB, middle montane wet evergreen broad-leaved forest; SWEB, semi-wet evergreen broad-leaved forest.

表6 云南3个常绿阔叶林样地的种子植物的地理成分 $\left(4\right.$ 个 $1 \mathrm{hm}^{2}$ 样方资料)

Table 6 Geographical elements of seed plants at species level for each of the four $1 \mathrm{hm}^{2}$ plots from the three evergreen broad-leaved forests in Yunnan

\begin{tabular}{|c|c|c|c|c|c|c|c|c|}
\hline \multirow[t]{2}{*}{$\begin{array}{l}\text { 种的地理成分 } \\
\text { Geographical elements at specific level }\end{array}$} & \multicolumn{2}{|c|}{$\begin{array}{l}\text { 季风常绿阔叶林样地 } 1 \\
\text { MEB plot } 1\end{array}$} & \multicolumn{2}{|c|}{$\begin{array}{l}\text { 半湿润常绿阔叶林样地 } \\
\text { SWEB plot }\end{array}$} & \multicolumn{2}{|c|}{$\begin{array}{c}\text { 石灰岩山半湿润 } \\
\text { 常绿阔叶林样地 } \\
\text { SWEB on limestone plot } \\
\end{array}$} & \multicolumn{2}{|c|}{$\begin{array}{c}\text { 中山湿性常绿阔叶林样地 } 1 \\
\text { MMEB plot } 1\end{array}$} \\
\hline & $\begin{array}{l}\text { 种数 } \\
\text { Species } \\
\text { number }\end{array}$ & $\begin{array}{c}\text { 种数比例 } \\
\text { Percent of species } \\
\text { number (\%) }\end{array}$ & $\begin{array}{l}\text { 种数 } \\
\text { Species } \\
\text { number }\end{array}$ & $\begin{array}{c}\text { 种数比例 } \\
\text { Percent of species } \\
\text { number (\%) }\end{array}$ & $\begin{array}{l}\text { 种数 } \\
\text { Species } \\
\text { number }\end{array}$ & $\begin{array}{c}\text { 种数比例 } \\
\text { Percent of species } \\
\text { number (\%) }\end{array}$ & $\begin{array}{l}\text { 种数 } \\
\text { Species } \\
\text { number }\end{array}$ & $\begin{array}{c}\text { 种数比例 } \\
\text { Percent of species } \\
\text { number (\%) }\end{array}$ \\
\hline 世界广布 Cosmopolitan & 1 & 0.30 & 1 & 0.61 & 1 & 0.78 & $\mathbf{0}$ & 0.00 \\
\hline 泛热带分布 Pantropic & 4 & 1.22 & 0 & 0.00 & 1 & 0.78 & 0 & 0.00 \\
\hline $\begin{array}{l}\text { 热带亚洲至热带美洲间断分布 } \\
\text { Tropical Asia and Tropical America disjuncted }\end{array}$ & 0 & 0.00 & 0 & 0.00 & 3 & 2.33 & 0 & 0.00 \\
\hline 旧世界热带分布 Old World Tropic & 4 & 1.22 & 2 & 1.22 & 1 & 0.78 & 0 & 0.00 \\
\hline $\begin{array}{l}\text { 热带亚洲至大洋洲分布 } \\
\text { Tropical Asia to Tropical Australia }\end{array}$ & 7 & 2.13 & 0 & 0.00 & 0 & 0 & 0 & 0.00 \\
\hline $\begin{array}{l}\text { 热带亚洲至热带非洲分布 } \\
\text { Tropical Asia to Tropical Africa }\end{array}$ & 4 & 1.22 & 2 & 1.22 & 1 & 0.78 & 1 & 0.70 \\
\hline $\begin{array}{l}\text { 热带亚洲(印度-马来西亚)分布 } \\
\text { Tropical Asia (Indo-Malesia) }\end{array}$ & 72 & 21.88 & 6 & 3.66 & 15 & 11.63 & 10 & 7.04 \\
\hline $\begin{array}{l}\text { 热带亚洲(南亚到大陆东南亚)分布 } \\
\text { Tropical Asia (South Asia to mainland South- } \\
\text { east Asia) }\end{array}$ & 49 & 14.89 & 20 & 12.20 & 9 & 6.98 & 14 & 9.86 \\
\hline $\begin{array}{l}\text { 热带亚洲(大陆东南亚)分布 } \\
\text { Tropical Asia (Mainland Southeast Asia) }\end{array}$ & 92 & 27.96 & 4 & 2.44 & 4 & 3.10 & 3 & 2.11 \\
\hline 热带成分合计 Tropical elements in all & 232 & 70.52 & 35 & 21.34 & 34 & 26.36 & 28 & 19.72 \\
\hline 北温带分布 North Temperate & 0 & 0.00 & 0 & 0.00 & 1 & 0.78 & 2 & 1.41 \\
\hline $\begin{array}{l}\text { 东亚和北美间断分布 } \\
\text { East Asia and North America disjuncted }\end{array}$ & 1 & 0.30 & 1 & 0.61 & 0 & 0.00 & 0 & 0.00 \\
\hline 旧世界温带分布 Old World Temperate & 0 & 0.00 & 0 & 0.00 & 5 & 3.88 & 0 & 0.00 \\
\hline 东亚分布 East Asia & 7 & 2.13 & 20 & 12.20 & 15 & 11.63 & 20 & 14.08 \\
\hline 中国-喜马拉雅分布 Sino-Himalayas & 7 & 2.13 & 49 & 29.88 & 19 & 14.73 & 36 & 25.35 \\
\hline 中国特有分布 Endemic to China & 43 & 13.07 & 44 & 26.83 & 49 & 37.98 & 39 & 27.46 \\
\hline 云南特有分布 Endemic to Yunnan, Cina & 38 & 11.55 & 15 & 9.15 & 5 & 3.88 & 17 & 11.97 \\
\hline 温带成分合计 Temperate elements in all & 96 & 29.18 & 129 & 78.66 & 94 & 72.87 & 114 & 80.28 \\
\hline 合计 Total & 329 & 100.00 & 164 & 100.00 & 129 & 100.00 & 142 & 100.00 \\
\hline
\end{tabular}

MEB, monsoon evergreen broad-leaved forest; MMEB, middle montane wet evergreen broad-leaved forest; SWEB, semi-wet evergreen broad-leaved forest. 
型的局部地段的物种组成，并不能代表整个植被类 型的植物区系。由于云南复杂的地形地貌和多样的 局部微环境造就了非常丰富的物种多样性这一事实, 为了增加对整个植被亚型的植物区系组成的认识, 我们也对整个植被类型层面的植物区系进行了比较 研究, 基于常绿阔叶林植被型的3个亚型的野生种 子植物名录, 在植被亚型层面分析了植物区系和生 物地理特征。

在植物科组成上, 按种数多少排名, 季风常绿 阔叶林的大科为兰科(233种)、豆科(102种)、茜草科
(98种)、菊科(82种)、唇形科(61种)、大戟科(59种)、 菖麻科(52种)等; 半湿润常绿阔叶林的大科为菊科 (198种)、禾本科(168种)、豆科(119种)、蓄薇科(119 种)、唇形科(77种)等; 中山湿性常绿阔叶林的大科 则为蓄薇科(60种)、杜鹃花科(40种)、菊科(36种)等 (表7)。

在植物属上, 季风常绿阔叶林种数较多的属为 石豆兰属 (Bulbophyllum)(36 种)、石斛属 (Dendrobium)(35种)、榕属(Ficus)(34种)、毛兰属Eria (14种)、栲属(Castanopsis)(14种)、猪屎豆属

表7 云南3个常绿阔叶林植被亚型层面的植物区系的优势科*

Table 7 Dominant families in species richness in the three evergreen broad-leaved forests at vegetation sub-type levels in Yunnan*

\begin{tabular}{|c|c|c|c|c|c|}
\hline \multicolumn{2}{|l|}{ 季风常绿阔叶林 MEB } & \multicolumn{2}{|l|}{ 半湿润常绿阔叶林 SWEB } & \multicolumn{2}{|c|}{ 中山湿性常绿阔叶林 MMEB } \\
\hline 优势科 Dominant family & 种数 No. of species & 优势科 Dominant family & 种数 No. of species & 优势科 Dominant family & 种数 No. of species \\
\hline 兰科 Orchidaceae & 233 & 菊科 Asteraceae & 198 & 蓄薇科 Rosaceae & 60 \\
\hline 豆科 Fabaceae & 102 & 禾本科 Poaceae & 168 & 杜鹃花Ericaceae & 40 \\
\hline 茜草科 Rubiaceae & 98 & 豆科 Fabaceae & 119 & 菊科 Asteraceae & 36 \\
\hline 菊科 Asteraceae & 82 & 蔷薇科 Rosaceae & 119 & 樟科 Lauraceae & 27 \\
\hline 唇形科 Lamiaceae & 61 & 唇形科 Lamiaceae & 77 & 唇形科 Lamiaceae & 26 \\
\hline 大戟科 Euphorbiaceae & 59 & 莎草科 Cyperaceae & 67 & 兰科 Orchidaceae & 25 \\
\hline 菖麻科 Urticaceae & 52 & 兰科 Orchidaceae & 63 & 百合科 Liliaceae & 23 \\
\hline 禾本科 Poaceae & 45 & 茜草科 Rubiaceae & 54 & 茜草科 Rubiaceae & 22 \\
\hline 樟科 Lauraceae & 44 & 毛莨科 Ranunculaceae & 50 & 山茶科 Theaceae & 22 \\
\hline 桑科 Moraceae & 44 & 玄参科 Scrophulariaceae & 50 & 菖麻科 Urticaceae & 22 \\
\hline 爵床科 Acanthaceae & 36 & 杜鹃花科 Ericaceae & 48 & 五加科 Araliaceae & 20 \\
\hline 壳斗科 Fagaceae & 33 & 蓼科 Polygonaceae & 45 & 毛莨科 Ranunculaceae & 20 \\
\hline 萝藦科 Asclepiadaceae & 31 & 龙胆科 Gentianaceae & 44 & 忍冬科 Caprifoliaceae & 18 \\
\hline 蓄微科 Rosaceae & 29 & 伞形科 Apiaceae & 42 & 禾本科 Poaceae & 18 \\
\hline 夹竹桃科 Apocynaceae & 27 & 忍冬科 Caprifoliaceae & 40 & 报春花科 Primulaceae & 18 \\
\hline 玄参科 Scrophulariaceae & 27 & 壳斗科 Fagaceae & 37 & 壳斗科 Fagaceae & 17 \\
\hline 天南星科 Araceae & 25 & 报春花科 Primulaceae & 36 & 龙胆科 Gentianaceae & 16 \\
\hline 五加科 Araliaceae & 25 & 菖麻科 Urticaceae & 32 & 玄参科 Scrophulariaceae & 16 \\
\hline 葡萄科 Vitaceae & 24 & 大戟科 Euphorbiaceae & 28 & 豆科 Fabaceae & 15 \\
\hline 楝科 Meliaceae & 23 & 茶科 Theaceae & 28 & 凤仙花科 Balsaminaceae & 12 \\
\hline 紫金牛科 Myrsinaceae & 23 & 樟科 Lauraceae & 27 & 桔梗科 Campanulaceae & 12 \\
\hline 鸭跖草科 Commelinaceae & 22 & 桔梗科 Campanulaceae & 26 & 蓼科 Polygonaceae & 12 \\
\hline 锦葵科 Malvaceae & 22 & 木樨科 Oleaceae & 23 & 小檗科 Berberidaceae & 11 \\
\hline 芸香科 Rutaceae & 22 & 石竹科 Caryophyllaceae & 20 & 山矾科 Symplocaceae & 11 \\
\hline 番荔枝科 Annonaceae & 21 & 葡萄科 Vitaceae & 20 & 冬青科 Aquifoliaceae & 10 \\
\hline 防己科 Menispermaceae & 21 & 萝藦科 Asclepiadaceae & 18 & 大戟科 Euphorbiaceae & 9 \\
\hline 姜科 Zingiberaceae & 21 & 天门冬科 Asparagaceae & 18 & 木樨科 Oleaceae & 9 \\
\hline 木樨科 Oleaceae & 18 & 紫草科 Boraginaceae & 17 & 五味子科 Schisandraceae & 9 \\
\hline 旋花科 Convolvulaceae & 17 & 苦苣苔科 Gesneriaceae & 17 & 菝喫科 Smilacaceae & 9 \\
\hline 苦芭苔科 Gesneriaceae & 16 & 鼠李科 Rhamnaceae & 16 & 芸香科 Rutaceae & 8 \\
\hline
\end{tabular}

*此表因是统计植被亚型所记录的植物区系, 为反映植被亚型植物区系科的组成特征, 按传统的科的大小范围来统计期其种数。

*Here the number of species in each plant family is censused on traditional circumscription of families. MEB, monsoon evergreen broad-leaved forest; MMEB, middle montane wet evergreen broad-leaved forest; SWEB, semi-wet evergreen broad-leaved forest. 
(Crotalaria)(13种)、胡椒属(Piper)(12种)、草麻属 (Boehmeria)(11种)等; 半湿润常绿阔叶林种数较多 (Polygonum)(30种)、臺草属(Carex)(29种)、蒿属 (Artemisia)(27种)、龙胆属(Gentiana)(25种)、悬钩子 属(Rubus)(25种)等; 中山湿性常绿阔叶林种数较多 的属则为杜鹃花属(Rhododendron)(17种)、悬钩子属 (16种)、凤仙花属(Impatiens)(12种)、石栋属(11种)、 山矾属(Symplocos)(11种)、冬青属(Ilex)(10种)等(表 8)。

植物区系地理成分上, 在科水平, 这 3 个常绿阔 叶林植被亚型均以热带分布科比例最高, 占总科数
的 $43 \%-56 \%$, 其次是世界分布科。热带分布科中以 泛热带分布科为主, 如爵床科、漆树科、无患子科 等。温带分布科占总科数的 $17 \%-26 \%$, 如桦木科、 忍冬科、壳斗科等, 并以北温带分布科为主。这 3 个 常绿阔叶林中, 季风常绿阔叶林的热带分布科比例 最高, 占总科数的 $56 \%$, 温带分布科仅占 $17 \%$ 。半湿 润常绿阔叶林和中山湿性常绿阔叶林的热带分布科 分别占 $46 \%$ 和 $43 \%$, 温带分布科占 $26 \%$, 二者显示了 类似的科的地理成分格局(表9)。

在属水平, 季风常绿阔叶林的热带分布属比例 最高, 占总属数的 $78.05 \%$, 并以热带亚洲分布属最

表8 云南3个常绿润叶林植被亚型层面的植物区系的优势属

Table 8 Dominant (top 30) genera in species richness in the three evergreen broad-leaved forests at vegetation sub-type levels in Yunnan

\begin{tabular}{|c|c|c|c|c|c|}
\hline \multicolumn{2}{|l|}{ 季风常绿阔叶林 MEB } & \multicolumn{2}{|l|}{ 半湿润常绿阔叶林 SWEB } & \multicolumn{2}{|c|}{ 中山湿性常绿阔叶林 MMEB } \\
\hline 优势属 Dominant genus & 种数 No. of species & 优势属 Dominant genus & 种数 No. of species & 优势属 Dominant genus & 种数 No. of species \\
\hline 石豆兰属 Bulbophyllum & 36 & 萹蓄属 Polygonum & 30 & 杜鹃花属 Rhododendron & 17 \\
\hline 石斛属 Dendrobium & 35 & 臺草属 Carex & 29 & 悬钩子属 Rubus & 16 \\
\hline 榕属 Ficus & 34 & 蒿属 Artemisia & 27 & 凤仙花属 Impatiens & 12 \\
\hline 毛兰属 Eria & 14 & 龙胆属 Gentiana & 25 & 石栋属 Lithocarpus & 11 \\
\hline 栲属 Castanopsis & 14 & 悬钩子属 Rubus & 25 & 山矾属 Symplocos & 11 \\
\hline 猪屎豆属 Crotalaria & 13 & 杜鹃花属 Rhododendron & 20 & 冬青属 Ilex & 10 \\
\hline 胡椒属 Piper & 12 & 铁线莲属 Clematis & 19 & 萹蓄属 Polygonum & 10 \\
\hline 荁麻属 Boehmeria & 11 & 珍珠菜属 Lysimachia & 17 & 报春花属 Primula & 10 \\
\hline 冬青属 Ilex & 11 & 木蓝属 Indigofera & 16 & 龙胆属 Gentiana & 9 \\
\hline 垚尾兰属 Oberonia & 11 & 马先蒿属 Pedicularis & 16 & 白珠树属 Gaultheria & 8 \\
\hline 蒲桃属 Syzygium & 11 & 报春花属 Primula & 16 & 木姜子属 Litsea & 8 \\
\hline 崖爬藤属 Tetrastigma & 11 & 栎属 Quercus & 15 & 珍珠菜属 Lysimachia & 8 \\
\hline 萹蓄属 Polygonum & 10 & 金丝桃属 Hypericum & 14 & 山茶属 Camellia & 7 \\
\hline 茄属 Solanum & 10 & 薯预属 Dioscorea & 13 & 柃属 Eurya & 7 \\
\hline 紫金牛属 Ardisia & 10 & 香薷属 Elsholtzia & 13 & 拉拉藤属 Galium & 7 \\
\hline 秋海棠属 Begonia & 10 & 堇菜属 Viola & 13 & 金丝桃属 Hypericum & 7 \\
\hline 大青属 Clerodendrum & 10 & 香茶菜属 Isodon & 12 & 菝葜属 Smilax & 7 \\
\hline 冷水花属 Pilea & 10 & 灯心草属 Juncus & 12 & 安息香属 Styrax & 7 \\
\hline 木姜子属 Litsea & 10 & 石栋属 Lithocarpus & 12 & 荚蒾属 Viburnum & 7 \\
\hline 杜英属 Elaeocarpus & 10 & 蓄薇属 Rosa & 12 & 小檗属 Berberis & 6 \\
\hline 贝母兰属 Coelogyne & 10 & 菝葜属 Smilax & 12 & 铁线莲属 Clematis & 6 \\
\hline 羊耳蒜属 Liparis & 9 & 荚蒾属 Viburnum & 12 & 香薷属 Elsholtzia & 6 \\
\hline 珍珠菜属 Lysimachia & 9 & 兔儿风属 Ainsliaea & 11 & 花楸属 Sorbus & 6 \\
\hline 耳草属 Hedyotis & 9 & 小檗属 Berberis & 11 & 猕猴桃属 Actinidia & 5 \\
\hline 楼梯草属 Elatostema & 9 & 莎草属 Cyperus & 11 & 秋海棠属 Begonia & 5 \\
\hline 瓜馥木属 Fissistigma & 9 & 卫矛属 Euonymus & 11 & 楼梯草属 Elatostema & 5 \\
\hline 玉叶金花属 Mussaenda & 9 & 大戟属 Euphorbia & 11 & 灯心草属 Juncus & 5 \\
\hline 玉凤花属 Habenaria & 9 & 柃属 Eurya & 11 & 女贞属 Ligustrum & 5 \\
\hline 石栎属 Lithocarpus & 9 & 拉拉藤属 Galium & 11 & 马先蒿属 Pedicularis & 5 \\
\hline 粗叶木属 Lasianthus & 8 & 山茶属 Camellia & 10 & 越橘属 Vaccinium & 5 \\
\hline
\end{tabular}

MEB, monsoon evergreen broad-leaved forest; MMEB, middle montane wet evergreen broad-leaved forest; SWEB, semi-wet evergreen broad-leaved forest. 
表9 云南3个常绿阔叶林植被亚型的植物区系科的地理成分

Table 9 Geographical elements of seed plants at the family level in the three evergreen broad-leaved forests at vegetation sub-type levels in Yunnan

科的地理成分

Geographical elements at family level

季风常绿阔叶林(164科) 半湿润常绿阔叶林(147 中山湿性常绿阔叶林 MEB (164 families)(\%)

科)

(110科) SWEB (147 families)(\%) MMEB (110 families)

(\%)

\begin{tabular}{lrrr}
\hline 世界分布 Cosmopolitan & $\mathbf{2 7}$ & $\mathbf{2 8}$ & $\mathbf{3 1}$ \\
泛热带分布 Pantropic & 42 & 34 & 29 \\
热带亚洲至热带美洲间断分布 Tropical Asia and Tropical America disjunct & 6 & 7 & 10 \\
旧世界热带分布 Old World Tropic & 4 & 3 & 2 \\
热带亚洲至大洋洲分布 Tropical Asia to Tropical Australia & 2 & 1 & 2 \\
热带亚洲至热带非洲分布 Tropical Asia to Tropical Africa & 0 & 0 & 0 \\
热带亚洲分布 Tropical Asia & 2 & 1 & 0 \\
热带成分合计 Tropical elements in total & $\mathbf{5 6}$ & $\mathbf{4 6}$ & $\mathbf{4 3}$ \\
北温带分布 North Temperate & 12 & 17 & 20 \\
东亚和北美间断分布 East Asia and North America disjunct & 4 & 5 & 2 \\
旧世界温带分布 Old World Temperate & 0 & 0 & 0 \\
温带亚洲分布 Temperate Asia & 0 & 0 & 0 \\
地中海、西亚至中亚分布 Mediterranean, West Asia to Central Asia & 0 & 1 & 0 \\
中亚分布 Central Asia & 0 & 0 & 0 \\
东亚分布 East Asia & 1 & 3 & 4 \\
中国特有分布 Endemic to China & 0 & 0 \\
温带成分合计 Temperate elements in total & 0 & $\mathbf{2 6}$ \\
合计 Total & $\mathbf{1 7}$ & $\mathbf{1 0 0}$ & $\mathbf{1 0 0}$
\end{tabular}

此表按传统的科地理分布(吴征镒等, 2003)进行分布区类型统计。

Here the distribution types of family is based on Wu et al. (2003) for their distribution. MEB, monsoon evergreen broad-leaved forest; MMEB, middle montane wet evergreen broad-leaved forest; SWEB, semi-wet evergreen broad-leaved forest.

为优势，占总属数的 $29.02 \%$ 。热带分布属包括泛热 带分布属, 如紫金牛属 (Ardisia)、羊蹄甲属 (Bauhinia)、山柑属(Capparis)、薯蓣属(Dioscorea)、 柿属(Diospyros)、榕属等; 热带亚洲分布属, 如黄肉 楠属(Actinodaphne)、茶梨属(Anneslea)、山茶属 (Camellia)、栲属、润楠属 (Machilus)、含笑属 (Michelia) 等; 旧世界热带分布属, 如天门冬属 (Asparagus)、楼梯草属(Elatostema)、洋荣莫属 (Euodia) 等; 热带亚洲与热带非洲间断分布属, 如 水麻属(Debregeasia)、姜花属(Hedychium)及铁仔属 (Myrsine) 等。半湿润常绿阔叶林和中山湿性常绿阔 叶林的热带分布属分别占 $44.91 \%$ 和 $44.04 \%$, 温带分 布属分别占 $46.29 \%$ 和 $48.19 \%$, 并具体以北温带分布 属比例最高, 各占18.36\%和19.95\%。温带分布属包 括北温带分布属, 如桤木属、桦木属、黄杨属 (Buxus)、我耳枥属(Carpinus)、山荣莫属(Cornus)、 松属(Pinus); 东亚分布属, 如狝猴桃属(Actinidia)、 桃叶珊瑚属(Aucuba)、青荚叶属(Helwingia)、茵芋 属 (Skimmia); 还包括中国特有属, 如双盾木属 (Dipelta)、鹭㽞草属(Diuranthera)、地涌金莲属 (Musella) 、栌菊木属 (Nouelia) 及瑤椒树属 www.plant-ecology.com
(Tapiscia)(表10)。显然, 季风常绿阔叶林与半湿润常 绿阔叶林和中山湿性常绿阔叶林有明显不同的地理 成分格局。

\section{6 三个常绿阔叶林植被亚型的比较}

这3个常绿阔叶林在含种数较多的世界分布的 大科上是类似的, 但在含种数较少的科上却明显不 同。例如，泛热带分布的番荔枝科、夹竹桃科、防 己科、桑科等, 在季风常绿阔叶林里有较高的种多 样性(丰富度), 但在半湿润常绿阔叶林和中山湿性 常绿阔叶林中种类不多; 在后二者中, 桔梗科、忍 冬科、杜鹃花科、龙胆科、报春花科、毛莨科和山 茶科却有较高的物种多样性。世界分布的大科紫草 科、石竹科和鼠李科在半湿润常绿阔叶林中种类较 多; 泛热带分布的风仙花科、菝契科和山矾科, 北 温带分布的小檗科以及东亚-北美间断分布的五味 子科均在中山湿性常绿阔叶林优势科之列。半湿润 常绿阔叶林和中山湿性常绿阔叶林有更多的共同优 势科。

在属的地理成分的比较上, 半湿润常绿阔叶林 和中山湿性常绿阔叶林有显著类似的格局(表10), 它们的热带分布属占总属数的 $44.91 \%$ 和 $44.04 \%$, 温 
带分布属各占 $46.29 \%$ 和 $48.19 \%$, 并以具体以北温带 分布属比例最高, 各占 $18.36 \%$ 和 $19.95 \%$ 。而季风常 绿阔叶林则显示了不同的地理成分格局: 热带分布 属占总属数的 $78.05 \%$, 并以热带亚洲分布属比例最 高, 占其总属数的 $29.02 \%$, 温带分布属占总属数的 $15.72 \%$ ，其中的北温带分布属仅占总属数的 $5.52 \%$ 。 显然, 季风常绿阔叶林在生物地理成分上热带性质 很明显。

这3个常绿阔叶林植被亚型的植物区系类似性 的比较显示, 在种的组成上, 半湿润常绿阔叶林与 中山湿性常绿阔叶林二者类似性达 $49.2 \%$, 但它们 与季风常绿阔叶林的类似性仅为 $17.1 \%$ 和 $15.4 \%$ 。半 湿润常绿阔叶林和中山湿性常绿阔叶林除生态外貌 特征有区别外, 在植物区系的地理成分很接近(表 11)。

\section{3 讨论}

在《云南植被》(吴征镒, 1987)中, 常绿阔叶林 植被型的季风常绿阔叶林植被亚型主要分布在云南 南部和西南部, 不仅树种多样性高, 除与其他 2 个常 绿阔叶林植被亚型的乔木层具共同优势的壳斗科、
山茶科和樟科外, 大戟科和茜草科种类也较多, 在 生态外貌上具有一定数量的大高位芽植物、更少的 地面芽植物及较多的复叶和全缘叶植物; 在种的地 理成分上，它的热带分布种占总种数的 $70.52 \%$, 其 中，热带亚洲分布种占总种数的 $64.73 \%$ 。这些特点 显示了它是一种与半湿润常绿阔叶林和中山湿性常 绿阔叶林不同的植被类型，它具有明显的热带亚洲 亲缘, 与东南亚的热带山地常绿润叶林类似(Ashton, 2003), 在性质上是一种热带山地的常绿榈叶林。

半湿润常绿阔叶林植被亚型主要分布在滇中 亚热带高原，乔木层除占优势的壳斗科和樟科外， 漆树科、桦木科和木樨科的种类也有较高的重要值。 清香木、黄连木、云南木樨榄、裂果漆(Toxicodendron griffithii), 以及榆科的云南鹅耳枥(Carpinus monbeigiana)和四荵朴(Celtis tetrandra)为石灰岩山生境 的常见种; 藤本植物和地面芽植物在石灰岩山生境 的半湿润常绿阔叶林中也更丰富。在种的地理成分 上, 半湿润常绿阔叶林中热带分布种占总种数的 $21.34 \%-26.36 \%$, 但以温带分布种为主, 在石灰岩 山生境, 中国特有种占到总种数的 $37.98 \%$ (表6)。

\begin{tabular}{|c|c|c|c|}
\hline $\begin{array}{l}\text { 属的地理成分 } \\
\text { Geographical elements at generic level }\end{array}$ & $\begin{array}{l}\text { 季风常绿阔叶林(834属) } \\
\text { MEB (834 genera)(\%) }\end{array}$ & $\begin{array}{c}\text { 半湿润常绿阔叶林(795 } \\
\text { 属) } \\
\text { SWEB (795 genera)(\%) }\end{array}$ & $\begin{array}{c}\text { 中山湿性常绿阔叶林 } \\
\text { (386属) } \\
\text { MMEB (386 genera)(\%) }\end{array}$ \\
\hline 世界分布 Cosmopolitan & 6.23 & 8.80 & 7.77 \\
\hline 泛热带分布 Pantropic & 21.94 & 17.61 & 14.51 \\
\hline 热带亚洲至热带美洲间断分布 Tropical Asia and Tropical America disjunct & 2.52 & 1.26 & 2.59 \\
\hline 旧世界热带分布 Old World Tropic & 10.31 & 7.04 & 5.44 \\
\hline 热带亚洲至大洋洲分布 Tropical Asia to Tropical Australia & 6.83 & 3.90 & 4.66 \\
\hline 热带亚洲至热带非洲分布 Tropical Asia to Tropical Africa & 7.43 & 5.28 & 3.37 \\
\hline 热带亚洲分布 Tropical Asia & 29.02 & 9.81 & 13.47 \\
\hline 热带成分合计 Tropical elements in total & 78.05 & 44.91 & 44.04 \\
\hline 北温带分布 North Temperate & 5.52 & 18.36 & 19.95 \\
\hline 东亚和北美间断分布 East Asia and North America disjunct & 2.76 & 5.41 & 6.74 \\
\hline 旧世界温带分布 Old World Temperate & 2.52 & 6.67 & 4.66 \\
\hline 温带亚洲分布 Temperate Asia & 0.00 & 1.51 & 0.52 \\
\hline 地中海、西亚至中亚分布 Mediterranean, West Asia to Central Asia & 0.12 & 0.50 & 0.00 \\
\hline 中亚分布 Central Asia & 0.00 & 0.13 & 0.00 \\
\hline 东亚分布 East Asia & 4.20 & 10.94 & 14.25 \\
\hline 中国特有分布 Endemic to China & 0.60 & 2.77 & 2.07 \\
\hline 温带成分合计 Temperate elements in total & 15.72 & 46.29 & 48.19 \\
\hline 合计 Total & 100.00 & 100.00 & 100.00 \\
\hline
\end{tabular}

MEB, monsoon evergreen broad-leaved forest; MMEB, middle montane wet evergreen broad-leaved forest; SWEB, semi-wet evergreen broad-leaved forest. 
表11 云南3个常绿榈叶林植被亚型植物区系科、属、种相似性的比较*

Table 11 Comparison of floristic similarities at the family, genera and specific levels in the three evergreen broad-leaved forests at vegetation sub-type levels in Yunnan*

\begin{tabular}{|c|c|c|c|c|}
\hline 植被亚型 Vegetation sub-type & & 半湿润常绿榈叶林 SWEB & 季风常绿阔叶林 MEB & 中山湿性常绿润叶林 MMEB \\
\hline \multirow{3}{*}{$\begin{array}{l}\text { 科 } \\
\text { Family level }\end{array}$} & SWEB & 100.0 & & \\
\hline & MEB & 87.6 & 100.0 & \\
\hline & MMEB & 96.4 & 89.2 & 100.0 \\
\hline \multirow{3}{*}{$\begin{array}{l}\text { 属 } \\
\text { Generic level }\end{array}$} & SWEB & 100 & & \\
\hline & MEB & 49.3 & 100.0 & \\
\hline & MMEB & 79.8 & 58.3 & 100.0 \\
\hline \multirow{3}{*}{$\begin{array}{l}\text { 种 } \\
\text { Specific level }\end{array}$} & SWEB & 100 & & \\
\hline & MEB & 17.1 & 100.0 & \\
\hline & MMEB & 49.2 & 15.4 & 100.0 \\
\hline
\end{tabular}

$\mathrm{A}$ 与 $\mathrm{B}$ 的相似性系数等于 $\mathrm{A}$ 和 $\mathrm{B}$ 共有的种数除以含种数较少的 $\mathrm{A}$ 或 $\mathrm{B}$ 的种数, 乘以 100 。

Similarity coefficient between A and B is the number of taxa shared by both A and B divided by the lowest number of taxa of A or B, multiplied by 100. MEB, monsoon evergreen broad-leaved forest; MMEB, middle montane wet evergreen broad-leaved forest; SWEB, semi-wet evergreen broad-leaved forest.

在本研究中，中山湿性常绿阔叶林植被亚型虽 也以壳斗科、樟科和山茶科植物为乔木层优势种, 但山矾科、冬青科及木兰科的种类在群落中有较高 的重要值。它的显著特征是有较高比例的附生植物, 并且在叶级谱上有更多的非全缘叶乔木。在种的植 物地理成分上, 与半湿润常绿阔叶林类似, 以温带 分布种占优势。中山湿性常绿阔叶林在生态外貌上 类似于亚洲的热带山地云雾林(Shi \& Zhu, 2009)或 苔藓常绿阔叶林(Ohsawa, 1991)。

在我们所做的 6 个 $1 \mathrm{hm}^{2}$ 样地里, 没有发现共同 的优势树种。季风常绿阔叶林在分布生境、植物区 系组成、物种多样性、生态外貌、地理成分上都与 半湿润常绿阔叶林和中山湿性常绿阔叶林区别明 显。在植物区系组成上, 它与东南亚热带低山森林 类似(Zhu, 2019)。半湿润常绿阔叶林和中山湿性常 绿阔叶林分布在云南亚热带山地, 二者有类似的物 种多样性, 均以温带分布种为主, 并以中国特有种 和中国-喜马拉雅分布种占优势, 是一类中国西南 的亚热带常绿阔叶林。毕竟半湿润常绿榈叶林和中 山湿性常绿阔叶林在生态外貌特征有区别, 把它们 处理为云南常绿阔叶林植被型下的 2 个植被亚型是 适合的(吴征镒, 1987)。反之, 在《云南植被》里的 季风常绿阔叶林植被亚型, 与热带季节性雨林的关 系远大于与半湿润常绿阔叶林和中山湿性常绿阔叶 林的关系。在普洱 $30 \mathrm{hm}^{2}$ 季风常绿阔叶林动态监测 样地与西双版纳预腊的 $20 \mathrm{hm}^{2}$ 热带季节性雨林样地 的比较上, 在预腊的 $20 \mathrm{hm}^{2}$ 热带季节性雨林样地里, 有 $9.76 \mathrm{hm}^{2}$ 的森林植被是与普洱样地里的季风常绿 阔叶林完全一样的以短刺栲和西南木荷占优势的群
落斑块, 为典型的季风常绿阔叶林 (李帅锋等, 2020)。我们的调查发现, 在西双版纳800-1000 m低 坡上的热带季节性雨林, 在被破坏后, 至少在一个 阶段, 往往演替为季风常绿阔叶林(即演替为以西 南木荷和短刺栲占优势的群落)。因此, 在云南南部, 季风常绿阔叶林与热带季节性雨林有密不可分的联 系。

中山湿性常绿阔叶林主要分布在在海拔2 000 $\mathrm{m}$ 以上山地云雾带, 它与半湿润常绿阔叶林在分布 海拔上有重叠, 但它始终是在半湿润常绿阔叶林地 带之上。这两类常绿阔叶林在云南的分布符合所谓 的海拔升高效应(Grubb, 1971), 即在大的山体植被 带会抬高, 在小的孤立山体植被带会下压。

在样方层面, 4 个 $1 \mathrm{hm}^{2}$ 样地的生活型谱显示: 季风常绿阔叶林乔木树种(相当于大高位芽+中高位 芽+小高位芽植物) 有 189 种, 占样地总种数的 $52.50 \%$; 非石灰岩山地的半湿润常绿阔叶林乔木树 种有 62 种, 占样地总种数的 $35.63 \%$; 石灰岩山地的 半湿润常绿阔叶林有乔木树种有 40 种, 占样地总种 数的 $27.78 \%$; 中山湿性常绿阔叶林样地记录乔木树 种 57 种, 占样地总种数的 $34.34 \%$ (表 4$)$ 。这一结果与 Spicer等(2020)的研究结果类似, 乔木树种实际仅占 样地各生活型总种数的一半以下(季风常绿阔叶林 稍高例外)。

在植被亚型层面的植物区系组成上, 这3个常 绿阔叶林种数最多的科(大科)均为世界分布科, 其 他各分布类型的科则为种数较少的科。在植物区系 地理成分上, 与样方层面植物种的地理成分构成类 似: 半湿润常绿阔叶林和中山湿性常绿阔叶林的热 
带分布属占总属数的 $44.91 \%$ 和 $44.04 \%$, 温带分布属 各占 $46.29 \%$ 和 $48.19 \%$, 并以北温带分布属比例最高, 各占 $18.36 \%$ 和 $19.95 \%$, 二者非常接近。季风常绿阔 叶林则显示了不同的地理成分格局: 热带分布属占 总属数的 $78.05 \%$, 并以热带亚洲分布属比例最高。 这3个常绿阔叶林在植被亚型层面的植物区系类似 性的比较显示, 半湿润常绿阔叶林与中山湿性常绿 阔叶林植物种的类似性达 $49.2 \%$, 但它们与低山常 绿阔叶林的类似性仅为 $17.1 \%$ 和 $15.4 \%$ 。

季风常绿阔叶林在《云南植被》中置于常绿阔 叶林植被型下, 给予植被亚型等级(吴征镒, 1987), 在新近建议的“中国常绿阔叶林分类试行方案”中, 它被放置在亚热带季节性常绿阔叶林植被型之下, 作为西部亚热带季节常绿阔叶林植被亚型, 给予了 新名称。而半湿润常绿阔叶林与中山湿性常绿阔叶 林则被放置在典型常绿阔叶林植被型下作为西部 (大陆)半湿润典型常绿阔叶林植被亚型(宋永昌, 2004，2011)。不论怎样, 常绿阔叶林植被型中的季 风常绿榈叶林植被亚型均被运用为分布在南亚热带 地区的水平地带性植被。根据本研究上述, 它是一 种热带森林向亚热带森林的过渡类型, 它具有热带 植物区系组成, 具有部分热带季节性雨林的生态外 貌特征, 它的分布区域与热带季节性雨林高度重叠, 即热带季节性雨林分布在热带北缘或南亚热带地区 的低海拔湿润沟谷和低坡上(在云南西南部和南部 通常在 $900 \mathrm{~m}$ 以下, 在云南东南部和广西西南部在 500-700 m以下, 在海南分布在 $800 \mathrm{~m}$ 以下地区), 可 以说是一种在水分、热量和分布海拔上均到了极限 条件的热带雨林类型(Zhu, 2017)。在同样区域, 仅 仅在热带季节性雨林之上或以北, 就直接过渡转变 为所谓的“季风常绿阔叶林”。这个过渡类型的“季风 常绿润叶林”, 在中国西南部表现为山地垂向过渡, 直接向半湿润常绿阔叶林和中山湿性常绿阔叶林过 渡, 在中国东南部, 则过渡到典型亚热带常绿阔叶 林, 为水平带过渡(Ashton \& Zhu, 2020)。基于这些 特征, 我们建议, 按其自然属性, 可能不宜将云南 的季风常绿阔叶林植被亚型放置在水平地带性植被 的亚热带常绿阔叶林植被型之下。建议它作为一个 单独的热带山地的植被类型, 并给予植被型等级, 它是一种热带低山常绿阔叶林。采用热带山地(低山) 常绿阔叶林这一名称，一方面考虑到其分布带上还 有亚热带常绿阔叶林植被型的中山湿性常绿阔叶林
和半湿润常绿阔叶林, 另一方面也与云南南部的热 带低地的季节性雨林相对应(Zhu et al., 2005, 2006, 2015, 2019; Zhu, 2006, 2019; 朱华等, 2015)。在传统 的云南常绿阔叶林的分类上, 都把乔木层主要由壳 斗科、樟科、山茶科和木兰科植物占优势的常绿阔 叶林, 统一归类为常绿阔叶林植被型, 只是依据它 们各自的特征, 划分为不同的植被亚型、群系等。 分布在中国热带北缘或南亚热带地区的“季风常绿 阔叶林植被亚型”, 具有热带雨林的一些特征; 在植 物区系组成上, 热带分布属、种占优势, 为热带季节 性雨林向亚热带常绿阔叶林的过渡类型。它不仅在 中国西南部体现为沿海拔的垂向过渡, 在东南部则 沿纬度水平地带性过渡。因此对“季风常绿阔叶林植 被亚型”的分类, 确需认真考虑。

从起源角度看, 云南常绿阔叶林植被型的这3 个常绿阔叶林植被亚型在科的组成上类似, 暗示了 它们可能有共同的早期起源, 后来发生了与云南的 地质历史事件密切联系的分异。在属、种组成上, 季 风常绿阔叶林现在已明显不同于半湿润常绿阔叶林 和中山湿性常绿阔叶林。季风常绿榈叶林演化为一 种热带山地植被, 半湿润常绿阔叶林和中山湿性常 绿润叶林演化为亚热带性质的植被。

在对云南植物区系的研究上, 认为云南植物区 系具有一个远古的热带起源背景, 在第三纪热带、 亚热带性质的东亚植物区系的基础上，随着喜马拉 雅的隆升, 世界性和北温带植物区系成分在北部地 区渗透、大量物种迅速形成, 而在南部地区, 因印度 支那地质板块向东南亚的逃逸, 热带亚洲成分渗 透、发展, 演化成以热带亚洲成分为主的热带植物 区系; 云南中部地区第三纪东亚植物区系成分有更 多的保持与承袭(Zhu, 2012, 2013, 2015, 2016; Liu et al., 2017; 朱华, 2018)。

Jacques等(2014)研究了云南中新世时的3个化 石点: 临沧、小龙潭和先锋的植物区系组成。晚中 新世时, 临沧化石点的海拔被建议是 $214 \mathrm{~m}$, 小龙 潭化石点是 $530 \mathrm{~m}$, 先锋化石点是 $1936 \mathrm{~m}$ 。这3个化 石点有以下特点: (1) 3 个化石点都以壳斗科和樟科 植物占优势, 但在临沧和小龙潭, 豆科植物明显更 多。(2)在科的地理成分上, 临沧化石点的泛热带分 布科占总科数的一半; 但在小龙潭化石点和先锋化 石点泛热带分布科仅占总科数的 $25 \%$, 温带分布科 在先锋化石点占到 $50 \%$ 。(3)在属的地理成分上, 临 
沧化石点热带分布属占总属数的 $64.1 \%$; 小龙潭化 石点热带分布属占总属数的 $53.7 \%$; 先锋化石点热 带分布属占总属数的 $47.1 \%$ 。这暗示了临沧化石点 是热带性质, 而先锋化石点是亚热带性质, 小龙潭 化石点居间, 这与它们当时的海拔相符合, 并显示 晚中新世时这3个化石点已发生了植物区系和植被 类型的分异。

把这 3 个常绿阔叶林植被亚型现在的分布与 3 个 化石点的研究叠加, 探讨其植物区系可能的演化。 对应于现在的植被分布, 临沧化石点在季风常绿阔 叶林范畴, 小龙潭化石点和先锋化石点在半湿润常 绿阔叶林范畴。现在云南的这 3 个常绿阔叶林植被亚 型都以壳斗科、樟科和豆科植物为乔木层的主要成 分, 半湿润常绿阔叶林和中山湿性常绿阔叶林的热 带分布属占总属数的 $44.91 \%$ 和 $44.04 \%$, 温带分布属 占 $46.29 \%$ 和 $48.19 \%$, 仍为亚热带性质, 但季风常绿 阔叶林热带分布属占总属数的 $78.05 \%$, 热带性质明 显。结合云南的地质历史和古植物学研究资料, 认 为云南的常绿阔叶林植物区系的分化在晚中新世就 已开始, 并随着海拔高度的改变和同步的全球变冷 而加强, 喜马拉雅隆升可能深刻影响了半湿润常绿 阔叶林和中山常绿阔叶林植物区系, 而伴随喜马拉 雅隆升发生的印度支那地质板块向东南逃逸, 深刻 影响了季风常绿阔叶林植物区系。这 3 个常绿阔叶林 植被亚型的植物区系组成的比较显示, 半湿润常绿 阔叶林与中山常绿阔叶林在科、属、种上的类似性 都比较高, 但它们与季风常绿阔叶林在种水平的类 似性很低。这也暗示了这3个常绿阔叶林植被亚型可 能有共同的早期起源, 后来发生了明显分异, 季风 常绿阔叶林演化为以热带成分为优势的热带亚洲的 山地常绿阔叶林(Zhu, 2019)。

最近的古植物学研究改变了我们对植被历史演 化的传统认识, 例如云南吕合盆地早渐新世(大约 3 300至3 200万年前)就已有了与现代该地区的植被 中几乎无形态学区别的栎属、桤木属、桦木属、我 耳枥属、榛属等植物(Tang et al., 2020); 甚至更早, 青藏高原的中部地区在4 700 万年前就已有了亚热 带森林植被(Su et al., 2020)。第四纪冰期可以说几乎 没有影响或改变云南植被的植物区系组成, 现在的 植被经历了远古植被的承袭渐变, 但没有巨变。结 合古植物学的发现研究植被地理, 以及在植被型的 层面, 对其植物区系和生物地理进行研究, 能为探
索植被类型的来龙去脉提供依据和线索(Zhu et al., 2020), 值得在植被地理研究上推荐。

\section{4 结论}

云南常绿阔叶林尽管都以壳斗科、山茶科、樟 科及木兰科树种占优势, 它们在植物区系组成、生 态外貌、地理成分及生境上是多样化的。分布在云 南南部和西南部的季风常绿润叶林以热带树种, 特 别是热带亚洲分布种占优势, 是东南亚热带山地常 绿阔叶林的一个类型。分布在云南亚热带至暖温带 地区的半湿润常绿阔叶林和中山湿性常绿阔叶林以 中国特有种和中国-喜马拉雅分布种占优势, 是中 国西南部独特的植被类型。半湿润常绿阔叶林主要 分布在云南高原, 而中山湿性常绿阔叶林分布在潮 湿的山地云雾带, 是一种山地云雾林。半湿润常绿 阔叶林和中山湿性常绿阔叶林因具有丰富的中国特 有种, 特别是前者, 目前在自然保护区外的地区仅 残存为受严重干扰的森林片断或为萌生灌从, 应给 予优先保护。

在植被亚型层面的植物区系地理上, 半湿润常 绿阔叶林和中山湿性常绿阔叶林在属水平具有类似 的地理成分格局, 显著不同于季风常绿阔叶林, 它 们的温带分布属各占 $46.29 \%$ 和 $48.19 \%$, 并以北温带 分布属比例最高, 各占 $18.36 \%$ 和 $19.95 \%$ 。季风常绿 阔叶林的热带分布属占总属数的 $78.05 \%$, 并以热带 亚洲分布属比例最高, 占其总属数的 $29.02 \%$ 。这3 类常绿阔叶林在种上的类似性很低。这些结果反映 了这3类常绿阔叶林植物区系已发生了分化。结合地 质历史事件和古植物学研究, 云南的常绿阔叶林植 物区系的歧化可能在晚中新世就已开始, 随着喜马 拉雅隆升及伴随的印度支那地质板块向东南逃逸, 云南地貌及海拔的改变和全球气候变冷及地区的干 旱化, 云南的常绿阔叶林植物区系的歧化不断加剧, 使之分化或演化成不同的植被类型或亚型。南部的 季风常绿阔叶林演化为以热带成分占优势的热带亚 洲的一种热带山地常绿阔叶林。半湿润常绿阔叶林 和中山湿性常绿阔叶林演化为与中国东部地区典型 亚热带常绿洞叶林对应的西部山地的亚热带常绿阔 叶林。考虑到这些众多的不同, 建议至少在中国西 南部, 云南常绿阔叶林植被型中的“季风常绿阔叶 林, 应作为一个单独的热带山地的植被类型, 并给 予植被型等级, 建议命名为热带低山常绿阔叶林。 


\section{参考文献}

Ashton P, Zhu H (2020). The tropical-subtropical evergreen forest transition in East Asia: an exploration. Plant Diversity, 42, 255-280.

Ashton PS (2003). Floristic zonation of tree communities on wet tropical mountains revisited. Perspectives in Plant Ecology, Evolution and Systematics, 6, 87-104.

Chase MW, Reveal JL (2009). A phylogenetic classification of the land plants to accompany APG III. Botanical Journal of the Linnean Society, 161, 122-127.

Curtis JT, McIntosh RP (1951). An upland forest continuum in the prairie-forest border region of Wisconsin. Ecology, 32, 476-496.

Ding WN, Ree RH, Spicer RA, Xing YW (2020). Ancient orogenic and monsoon-driven assembly of the world's richest temperate alpine flora. Science, 369, 578-581.

Grubb PJ (1971). Interpretation of the "Massenerhebung" effect on tropical mountains. Nature, 229, 44-45.

Huang YJ, Jia LB, Wang Q, Mosbrugger V, Utescher T, Su T, Zhou ZK (2016). Cenozoic plant diversity of Yunnan: a review. Plant Diversity, 38, 271-282.

Jacques FMB, Shi GL, Su T, Zhou ZK (2015). A tropical forest of the middle Miocene of Fujian (SE China) reveals SinoIndian biogeographic affinities. Review of Palaeobotany and Palynology, 216, 76-91.

Jacques FMB, Su T, Spicer RA, Xing YW, Huang YJ, Zhou ZK (2014). Late Miocene southwestern Chinese floristic diversity shaped by the southeastern uplift of the Tibetan Plateau. Palaeogeography, Palaeoclimatology, Palaeoecology, 411, 208-215.

Jin ZZ (1979). The types and characteristics of evergreen broad-leaved forests in Yunnan. Acta Botanica Yunnanica, 1, 90-105. [金振洲 (1979). 云南常绿阔叶林的类型和特 点. 云南植物研究, 1, 90-105.]

Li SF, Lang XD, Huang XB, Wang YH, Liu WD, Xu CH, Su JR (2020). Association classification of a $30 \mathrm{hm}^{2}$ dynamics plot in the monsoon broad-leaved evergreen forest in Pu'er, Yunnan, China. Chinese Journal of Plant Ecology, 44, 236-247. [李帅锋, 郎学东, 黄小波, 王艳红, 刘万 德, 徐崇华, 苏建荣 (2020). 云南普洱30 hm²季风常绿 阔叶林动态监测样地群从数量分类. 植物生态学报, 44 , 236-247.]

Liu ED, Peng H (2007). A preliminary floristic study on the midmontane humid evergreen broad-leaved forest in Yongde Snow Mountain, SW Yunnan, China. Acta Botanica Yunnanica，29，129-136. [刘恩德，彭华 (2007). 永德大雪山 中山湿性常绿阔叶林植物区系的初步研究. 云南植物 研究, 29, 129-136.]

Liu SY, Zhu H, Yang J (2017). A phylogenetic perspective on biogeographical divergence of the Flora in Yunnan, Southwestern China. Scientific Reports, 7, 43032. DOI: 10. 1038/srep43032.

Meng GT, Chai Y, Yuan CM, Ai HS, Li GX, Wang Q, Li PR, Lin RT (2013). Community characteristics of the midmontane humid ever-green broad-leaved forest in Gaoligong Mountains, Yunnan. Scientia Silvae Sinicae, 49(3), 144-151. [孟广涛, 柴勇, 袁春明, 艾怀森, 李贵祥, 王 骞, 李品荣, 萄汝涛 (2013). 云南高黎贡山中山湿性常 绿阔叶林的群落特征. 林业科学, 49(3), 144-151.]

Mueller-Dombois D, Ellenberg H (1974). Aims and Methods of Vegetation Ecology. John Wiley \& Sons, New York.

Ohsawa M (1991). Structural comparison of tropical montane forests along latitudinal and altitudinal gradients in south and east Asia. Vegetatio, 97, 1-10.

Peng H, Wu ZY (1998). The preliminary floristical study on mid-montane humid evergreen broad-leaved forest in Mt. Wuliangshan. Acta Botanica Yunnanica, 20, 12-22. [彭华, 吴征镒 (1998). 无量山中山湿性常绿阔叶林及其植物 区系的初步研究. 云南植物研究, 20, 12-22.]

Raunkiaer C (1934). The Life Forms of Plants and Statistical Plant Geography. Oxford University Press, London.

Shi JP, Zhu H (2009). Tree species composition and diversity of tropical mountain cloud forest in the Yunnan, southwestern China. Ecological Research, 24, 83-92.

Song YC (2004). Tentative classification scheme of evergreen broad-leaved forests of China. Acta Phytoecologica Sinica, 28, 435-448. [宋永昌 (2004). 中国常绿阔叶林分类试行 方案. 植物生态学报, 28, 435-448.]

Song YC (2011). Recognition and proposal on the vegetation classification system of China. Chinese Journal of Plant Ecology, 35, 882-892. [宋永昌 (2011). 对中国植被分类 系统的认知和建议. 植物生态学报, 35, 882-892.]

Spicer ME, Mellor H, Carson WP (2020). Seeing beyond the trees: a comparison of tropical and temperate plant growth forms and their vertical distribution. Ecology, 101, e02974. DOI: 10.1002/ecy.2974.

Su T, Spicer RA, Wu FX, Farnsworth A, Huang J, del Rio C, Deng T, Ding L, Deng WYD, Huang YJ, Hughes A, Jia LB, Jin JH, Li SF, Liang SQ, et al. (2020). A Middle Eocene lowland humid subtropical "Shangri-La" ecosystem in central Tibet. Proceedings of the National Academy of Sciences of the United States of America, 117, 32989-32995.

Tang CQ (2015). Distribution patterns of the subtropical evergreen broad-leaved forests of southwestern China, as compared with those of the eastern Chinese subtropical regions. Collectanea Botanica, 34, e006. DOI: 10.3989/collectbot.2015.v34.006.

Tang H, Li SF, Su T, Spicer RA, Zhang ST, Li SH, Liu J, Lauretano V, Witkowski CR, Spicer TEV, Deng WYD, Wu MX, Ding WN, Zhou ZK (2020). Early Oligocene vegetation and climate of southwestern China inferred from palynology. Palaeogeography, Palaeoclimatology, Palaeoeco- 
logy, 560, 109988. DOI: 10.1016/j.palaeo.2020.109988.

The Angiosperm Phylogeny Group (2009). An update of the Angiosperm Phylogeny Group classification for the orders and families of flowering plants: APG III. Botanical Journal of the Linnean Society, 161, 105-121.

Wang LS, Peng H (2004). The preliminary floristic study on the elements of Lithocarpus variolosa forest in Mt. Xiaobaicaoling, C. Yunnan. Acta Botanica Yunnanica, 26, 157-165. [王利松, 彭华 (2004). 滇中小百草岭多变石 栎林植物区系的初步研究. 云南植物研究, 26, 157-165.]

Webb LJ (1959). A physiognomic classification of Australian rain forests. Journal of Ecology, 47, 551-570.

Wu ZY (1987). Vegetation of Yunnan. Science Press, Beijing. 97-143. [吴征镒 (1987). 云南植被. 科学出版社, 北京. 97-143.]

Wu ZY (1991). The areal-types of Chinese genera of seed plants. Acta Botanica Yunnanica, S4, 1-139. [吴征镒 (1991). 中 国种子植物属的分布区类型. 云南植物研究, S4, 1-139.]

Wu ZY, Zhou ZK, Li DZ, Peng H, Sun H (2003). The arealtypes of the world families of seed plants. Acta Botanica Yunnanica, 25, 245-257. [吴征镒, 周浙昆, 李德铢, 彭 华, 孙航 (2003). 世界种子植物科的分布区类型系统. 云南植物研究, 25, 245-257.]

Wu ZY, Zhou ZK, Sun H, Li DZ, Peng H (2006). The ArealTypes of Seed Plants and Their Origin and Differentiation. Yunnan Science and Technology Press, Kunming. [吴征 镒, 周浙昆, 孙航, 李德铢, 彭华 (2006). 种子植物分 布区类型及其起源和分化. 云南科技出版社, 昆明.]

Zhu H (1997). Ecological and biogeographical studies on the tropical rain forest of south Yunnan, SW China with a special reference to its relation with rain forests of tropical Asia. Journal of Biogeography, 24, 647-662.

Zhu H (2006). Forest vegetation of Xishuangbanna, south China. Forestry Studies in China, 8(2), 1-58.

Zhu H (2008). Distribution patterns of genera of Yunnan seed plants with references to their biogeographical significances. Advances in Earth Science, 23, 830-839. [朱华 (2008). 云南种子植物区系地理成分分布格局及其意义. 地球科学进展, 23, 830-839.]

Zhu H (2012). Biogeographical divergence of the flora of Yunnan, southwestern China initiated by the uplift of Himalaya and extrusion of Indochina block. PLOS ONE, 7, e45601. DOI: 10.1371/journal.pone.0045601.

Zhu H (2013). The floras of southern and tropical southeastern Yunnan have been shaped by divergent geological histories. PLOS ONE, 8, e64213. DOI:10.1371/journal.pone. 0064213.

Zhu H (2015). Geographical patterns of Yunnan seed plants may be influenced by the clockwise rotation of the SimaoIndochina geoblock. Frontiers in Earth Science, 3, 53. DOI: 10.3389/feart.2015.00053.

Zhu H (2016). A biogeographical comparison between Yunnan, southwest China, and Taiwan, southeast China, with implications for the evolutionary history of the East Asian flora. Annals of the Missouri Botanical Garden, 101, 750771.

Zhu H (2016). Discussion on the origin of the mid-montane wet evergreen broad-leaved forest in Yunnan. Plant Science Journal, 34, 715-723. [朱华 (2016). 云南中山湿性常绿 阔叶林起源的探讨. 植物科学学报, 34, 715-723.]

Zhu H (2017). The tropical forests of southern China and conservation of biodiversity. The Botanical Review, 83, 87-105.

Zhu H (2018). Origin and evolution of the flora of Yunnan. Plant Science Journal, 36, 32-37. [朱华 (2018). 云南植 物区系的起源与演化. 植物科学学报, 36, 32-37.]

Zhu H (2019). Floristic divergence of the evergreen broadleaved forests in Yunnan, southwestern China. Phytotaxa, 393, 1-20.

Zhu H, Cao M, Hu HB (2006). Geological history, flora, and vegetation of Xishuangbanna, southern Yunnan, China. Biotropica, 38, 310-317.

Zhu H, Chai Y, Zhou SS, Yan LC, Shi JP, Yang GP (2016). Combined community ecology and floristics, a synthetic study on the upper montane evergreen broad-leaved forests in Yunnan, southwestern China. Plant Diversity, 38, 295302.

Zhu H, Shi JP, Zhao CJ (2005). Species composition, physiognomy and plant diversity of the tropical montane evergreen broad-leaved forest in southern Yunnan. Biodiversity and Conservation, 14, 2855-2870.

Zhu H, Tan YH, Yan LC, Liu FY (2020). Flora of the savannalike vegetation in hot dry valleys, southwestern China with implications to their origin and evolution. The Botanical Review, 86, 281-297.

Zhu H, Wang H, Li BG, Zhou SS, Zhang JH (2015). Studies on the forest vegetation of Xishuangbanna. Plant Science Journal, 33, 641-726. [朱华, 王洪, 李保贵, 周仕顺, 张 建侯 (2015). 西双版纳森林植被研究. 植物科学学报, 33, 641-726.]

Zhu H, Yan LC (2009). List of Seed Plants in the Ailao Mts. of Yunnan Province, China. Yunnan Science \& Technology Press, Kunming. [朱华, 间丽春 (2009). 云南哀牢山种 子植物. 云南科技出版社, 昆明.]

Zhu H, Yong C, Zhou SS, Wang H, Yan LC (2015). Vegetation, floristic composition and species diversity in a tropical mountain nature reserve in southern Yunnan, SW China with implications for conservation. Tropical Conservation Science, 8, 528-546.

Zhu H, Zhou SS, Yan LC, Shi JP, Shen YX (2019). Studies on the evergreen broad-leaved forests of Yunnan, southwestern China. The Botanical Review, 85, 131-148.

特邀编委: 刘 庆 编辑: 赵 航 